\$B 001792 





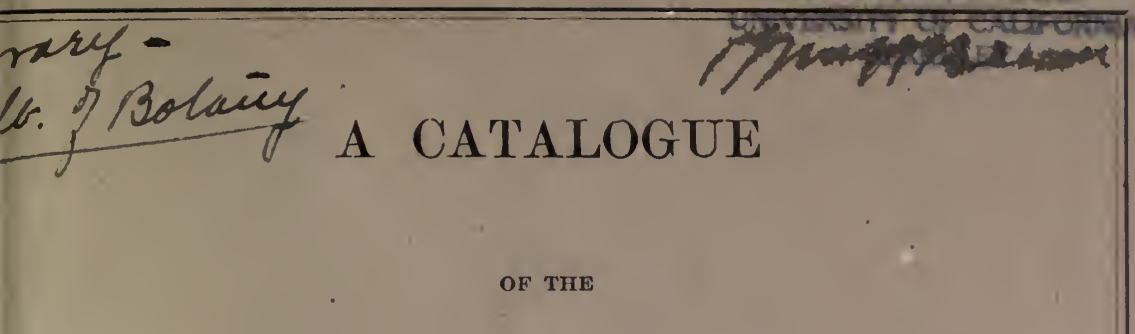

Forest Trees of the United States

WHICH

USUALLY ATTAIN A HEIGHT OF SIXTEEN FEET OR MORE,

WITH

NOTES AND BRIEP DESCRIPTIOIS OR TIL MORE IMPORTANT SPECIES,

ILLUSTRATING THE

COLLECTION OF FOREST-TREE SECTIONS ON EXHLBITION BY THE DEPARTMENT OF AGRICULTURE AT THE CENTENNIAL EXHIBITION, PHILADELPHIA.

PREPARED BY

GEO. VASEY, M. D.

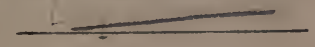

W A S H I N G TON :

GOVERNMENT PRINTING OFFICE.

1876 . 



\section{A CA'TALOGUE}

OF TIIE

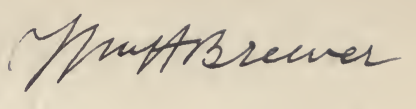

Forest Trees of tile United States

WHICH

USUALLY ATTAIN A HEIGHT OF SIXTEEN FEET OR MORE,

WITII

NOTES AID BRIEP DESCRIPTIOIS OP TIRE MORE INPORTAIT SPECIES,

ILLUSTRATING THE

COLLECTIOT OF FOREST-TREE SECTIONS ON EXHLBITION BY THE DEPARTMENT

OF AGRICCLTURE AT THE CENTENNIAL EXHIBITION, PHILADELPHIA.

PREPARED BX

GEO. VASEY, M. D.

DEPARTMENT OF BOTANY

UNIVEKSITY OF CAL!EO??!IA

WA SH I N G TON:

GOVERNMENT PRINTING OFFICE.

1876 . 
1

l 


\title{
FOREST TREES OF THE UNITED STATES.
}

\author{
CENTENNIAL COLLECTION.
}

\section{ADITIONS ANI GORRECTIONS.}

No. 420. Juniperus pachyphlnea. 'Torr.-'Thick-barked Celar.-A pretty large sprobling tree of $A$ rizona. 'The bark is rongh and checked like the bark of No. 381. Abies sub-alpinir and sweet, and are used as food by the Indians.

synonymous with A. lasioearpa, Hook. Engelmann now concludes that this is No. 364. 'The wood section

'I'he true P. Balfouriana has of this number are probably Pinus aristata. Eng. -pecimens in the collection.

tecurately ascortaineds of Oak from Arizona were packed befort the names were $707 \mathrm{E}$ is Quercus Emoryi, 'Torr. or Nombered $707 \mathrm{E}$ and $708 \mathrm{E}$. 'The first, No.

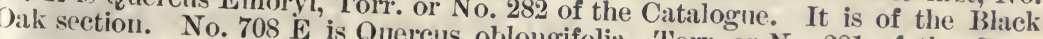
ogue. It is of the White Oak section,

proper botanical specimens at the right season, and, having carefully noted the localities, to return at the end of the growing period and obtain sections of the trees.

As collector for the Southern States, Mr. A. H. Curtiss, of Libert5, Ta., a well-known botanist, was engaged.

A large number of the trees of the Middle States were obtained in the vicinity of Washington. Of these, thirty species were procured from a part of the General Washington estate at Mount Vernon, now owned by Dr. E. P. Howland.

The trees peculiar to the New England States were procured b5 Mr. C. G. Pringle, of Charlotte, Vt.

As collector for the Western States, Mr. John Wolf, of Canton, Ill., was employed. In making the collection in Colorado, he was assisted by Mr. C. W. Derry, of Granite, Lake County, Colorado.

The semi-tropical trees of Southern Florida were obtained by Dr. A. 


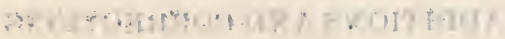

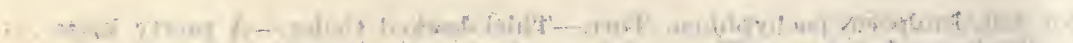

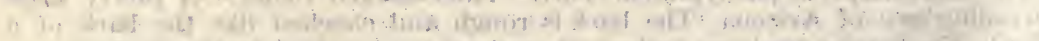

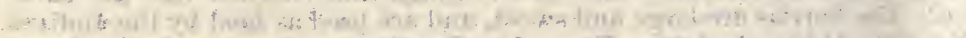

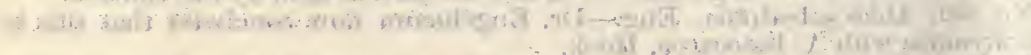

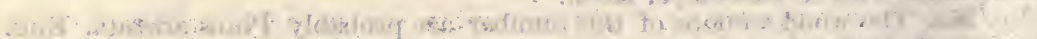

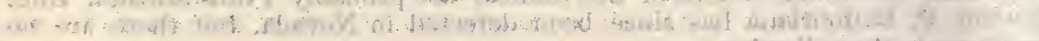
o(iv):

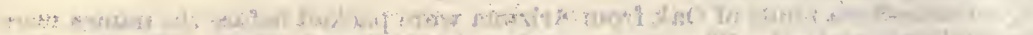
$\%$.

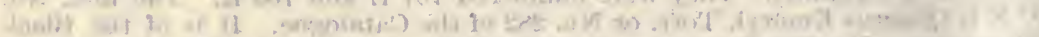

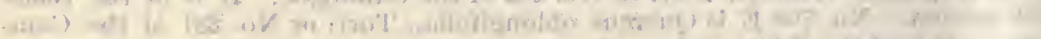




\section{FOREST TREES OF THE UNITED STATES.}

\section{CENTENNIAL COLLECTION.}

Sir: The following list is a catalogue of the native and naturalized forest-trees of the United States which attain a height of 16 feet and upward. Descriptive notes of many species are appended.

By an act of the last Congress an appropriation was made to enable the different Departments of the Government to participate in the Centennial Exposition of 1876. In pursuance of this object, the Botanist of the Department of Agriculture undertook to make a collection to represent the trees of the United States. The aim was to represent every important tree by botanical specimens of the leaves, flowers, and fruit, and also by sections of the trunk, showing the appearance of the bark and of the wood; thus giving the completest possible view of every species. The great extent of our country and the immense rariety of our arborescent vegetation made this of necessity a great undertaking. Well knowing that the chief value of such a collection would depend upon its scientific accuracy, arrangements were made to engage competent persons in the different fields of labor. In some portions of the country, local botanists were emplosed to collect the trees of their particular districts. But for the larger portion of the country it was necessary to employ traveling-agents, whose duty it was to explore a desig. nated section, ascertain the localities of the trees desired, collect the proper botanical specimens at the right season, and, having carefully noted the localities, to return at the end of the growing period and obtain sections of the trees.

As collector for the Southern States, Mr. A. H. Curtiss, of Liberty, Va., a well-known botanist, was engaged.

A large number of the trees of the Middle States were obtained in the vicinity of Washington. Of these, thirty species were procured from a part of the General Washington estate at Mount Vernon, now owned by Dr. E. P. Howland.

The trees peculiar to the New England States were procured bs Mr. C. G. Pringle, of Charlotte, Vt.

As collector for the Western States, Mr. John Wolf, of Canton, Ill., was employed. In making the collection in Colorado, he was assisted by Mr. C. W. Derry, of Granite, Lake County, Colorado.

The semi-tropical trees of Southern Florida were obtained by Dr. A. 
W. Chapman, of Apalachicola, duriug a two months' cruise by schooner on the west coast, among the various keys and inlets, and far into the interior by the Caloosahatchee River. Dr. Chapman is an old resident of Florida, author of the "Flora of the Southern States," and better acquainted with the vegetation of that region than any other person.

A portion of the trees of Texas were obtained by Dr. S. B. Buckley, of Austin, whose labors in developing the botany of that section are well known; and a portion were collected by Dr. F. G. Lindheimer, a veteran botanist, whose collections of Texas plants, made many years ago, enrich the principal herbaria of the country.

In Utah, Mr. L. F. Ward, botanist of the survey of the Colorado River by Messrs. Powell and Thompson, made the collection of the trees of that region.

The trees of the high sierras of California and Nevada were procured by Mr. J. G. Lemmon, of Sierra County, Ualifornia. The magnificent conifers of that region are represented by large wedge-sbaped sections of trees from 4 to 7 feet in diameter, the preparation of which cost a great amount of toil and expense. The immense trees had to be felled, and the desired sections removed by sawing and splitting with wedges until the portions' were reduced to proper size.

The trees of the Pacific slope in California were collected by Mr. G. R. Vasey, with valuable aid and assistance from Dr. A. Kellogg, of San Francisco, Dr. J. G. Cooper, and others.

Dr. Edward Palmer made the collection for the southern portion of California, Arizona, and Southern Utah.

Mr. A. J. Dufur, Centennial Commissioner for Oregon, collected the peculiar trees of that State.

After the woods were received at Washington, they were taken to a mill and reduced to the uniform length of two feet; then each section was divided by sawing longitudinally into two pieces, which were planed on the sawed surface, one arranged to show the outer or bark surface and the other to show the grain of the wood, its color, density, \&c.

The corresponding botanical specimens for each species are displayed in frames arranged in the immediate vicinity of the trees to which they

- belong. By this means, an intelligent view of the appearance and properties of every species of the trees of the countrymay be obtained.

Great difficulty was experienced in deciding upon the limitations of height and size which should characterize a tree. It is well knowu that certain plants which are only shrubs in some places become large trees in other places; sometimes the difference depending on climate and some. times on other circumstances. Thus, Magnolia glauca, or White Bay, grows and matures its flowers and fruit in some portions of Massachusetts, where it attains only the size of a large shrub. It, however, steadily increases in size in situations farther south, until in Georgia and Florida it attains the size of a large tree. In some places, the same plant appears as a shrub or a tree, under different circumstances, in closely contiguous localities. Dr. Chapman, who inade the collection of the trees of South Florida, says: "I was much disappointed in the size of most of the forest growth in that region. A peculiarity of these tropical trees is, that for miles they occur to you as mere shrubs, when at some other locality sou find them lofty trees." As a general rule, I have not admitted into the collection any tree which does not, under favorable circumstances, attain a height of 20 feet and a diameter of 4 inches. Yet, in a few cases, in order the more fully to illustrate a family, a tree has been admitted which would fall below that standard. The 
accompanying catalogue enumerates about 400 species, the greater portion of which are represented by specimens in the collection.

Some portions of the country have been so incompletely explored that our knowledge of their vegetation is imperfeet; yet it is probable that this catalogue presents, with great accuracy, our present knowledge of the trees of the United States. In two or three instances only, foreign species have been admitted, because of their extensive naturalization in some sections.

The two largest genera of trees are the oaks and the pines, of which we have about 30 species of each. Of coniferous trees, including the Pines, Firs, Cedars, Larches, Cypress, Sequoias, \&c., we have about 60 species. The Rose family, including the Plums, Cherries, Thorns, \&c., is represented by over 30 species. Of the order Leguminosc, or trees of the pod-bearing family, we have orer 20, embracing the Locusts, Acacias, Redbuds, Mesquits, \&c. Of ericaceous trees we have 8 species, including the Californian Manzanita and Madrone trees, the Sorrel tree of the Southern States, and others. Of Maples we have 8; of Magnolias, 7 ; of Ash, 11; of Elms, 6; of Walnuts and Hickorys, 13; of Poplars, 8; and of Birch, 6 species.

The usual difficulty has been encountered of deciding as to the standing of certain forms which some botanists regard as species and others as only varieties. In most well-marked cases, these are entered in the catalogue under distinct numbers, either as species or as varieties, as the evidences in the case seemed most convincing.

The range, or botanical region, of each species is indicated in a general manner, thus: Those trees which occur more or less extensively over the whole or the larger portion of the country east of the base of the Rocky Mountains or east of the Mississippi River are marked Easteru United States. This region is subdivided, by a line running eastrard from the mouth of the Ohio River to the Atlantic, into two portions, one of which is called Northeastern United States, and the other Southeastern United States. Other localities are indicated as Southern States, New Eugland States, Western States, Alleghany Mountaius, \&c. The western portion of the United States and Territories is marked in detached regions, as follows: Rocky Mountains of Colorado, or Rocky Mountains of Colorado and Utah; Sierra Nevada Mountains of California, Oregon, and Washington Territory; California; Sonthern California; Arizona. The portion of the country adjoining the Mexican border is indicated by the locality Westeru Texas and westward.

Certain portions of our country have not yet lieen sufficiently explored to determine accurately all the species of trees thereto belonging, This is the case with respect to the southern portion of Florida. Some species which at one time were thought to be indigenous in that region have not been confirmed by any late investigations, and will probably have to be erased from our list. The same difficulty occurs with respect to some of the trees of the Rocks Mountaius and the western coast, particularly the Conifers and the Willows.

In the short time allotted to making this collection, it has not been possible to obtain wood specimens of every species given in the catalogue. The number wanting, however, is but a small percentage of the whole.

Among the good results growing out of this work, we may mention, first, that much information has been gained respecting species hitherto imperfectly known; and, secondly, that four or five new species, or species before unknown to our flora, have been obtained. These are mainly in South Florida, and include two exogens, viz, an Anoua or Custard 
Apple, and a Chrysophyllum or Star Apple; and one endogen, a Palm of the genus Thrinax.

I wish to record my sincere thanks to the Hon. F. Watts, Commissioner, and to Mr. William Saunders, Centennial Agent of the Department, for all possible assistance rendered in the prosecution of the work.

Respectfully,

GEO. VASEY,

- Botanist.

Hon. Fred. WATT'S,

Commissioner.

\section{MagnoliaCe A.}

No.1. Magnolia grandiflora, L.-Evergreen Mragnolia.-Southern States. A large and beautiful tree, with thick glossy evergreen leaves, and large white flowers, which are exceedingly fragrant.

No. 2. Magnolia glauca, L.-Sweet Bay; White Bay.-Massachusetts southward. Northward, this is only a small tree or shrub; but in the South it attains a large size, and the leaves become evergreen.

No. 3. Magnolia Umbrella, Lam.-Umbrella Tree.-Southern States; Alleghany Mountains.

No. 4. Magnolia acuminata, L.-Cucumber Tree.-New York; South and West. This species has a greater range to the northward, where it sometimes attains a large size.

No. 5. Magnolia cordata, Michx.-Yellow Cucumber Tree.-Southern States.

No. 6. Magnolia Fraseri, Walt.-Long-leared Cucumber Tree.-Southern States.

No. 7. Magnolia macrophylla, Michx.-Large-leaved Umbrella Tree.Southern States.

No. 8. Liriodendron tulipifera, L.-Tulip Tree; Yellow Poplar.-Eastern United States. One of the largest and most beautiful of North American trees. In the Western States, it attains an immense size. It is found principally in the rich bottom-lands of the large rivers, where its wood is extensively employed for building purposes and for the manufacture of furniture. As an ornamental tree, it is hardly surpassed by any other ; its form being regular, its foliage peculiar and pleasing, and its abundant flowers, though not highly colored, are yet rery beautiful.

\section{ANONACEA.}

No. 9. Anona.-Custard Apple.-Southern Florida. Discovered by Dr. Chapman in South Florida. It grows 15 to 20 feet high. The fruit is small and eatable when fully ripe. The species is undetermined.

No. 10. Asimina triloba, Dunal.-Papaw.-From Pennsylvania southward. A small tree, very common in the Southern States, less frequent at the North. It produces an oblong pulpy fruit about 4 inches long, which when ripe has a rich luscious taste.

\section{Capparidace As.}

No. 11. Capparis Jamaicensis, Jacq.-Caper Tree.-South Florida. A shrub or small tree of South Florida, also growing in the West Indies. The true capers of commerce are the fruit of the Old World species. 


\section{Canellace E.}

No. 12. Canella allia, Strartz.-White Wood; Wild Cinnamon.--South Florida. A small tree in South Florida. In the West Indies, it is abundant, and called Wild Cinnamon and White Wood. The bark is aromatic and tonic, and is much employed in medicine.

\section{TAMARISCINE $\mathrm{E}$.}

No. 13. Fouquiera splendens, Eng.-Western Texas and Arizona. Grows in Western Texas, and thence westward to Sonthern California. In our borders, it is usually only a shrub; but in Mexico it grows 20 to 30 feet high, and on account of its spiny branches is used for hedges and fences.

\section{GutTiFER A.}

No. 14. Clusia flava.-South Florida. A West Indian tree, said to have been found in Florida, but not recently observed.

\section{Ternstromace E.}

No. 15. Gordonia Lasianthus, L.-Loblolly Bay.-Southern States. A tree 30 to 50 feet high, growing in swamps near the sea-coast from North Carolina to Florida and Louisiana. The leaves are evergreen; the flowers showy white, and sweet-scented. The bark is much employed in tanning, as a substitute for oak-bark.

No. 16. Gordonia pubescens, L'H.-Mountain Bas.-Southern States. A small tree rarely over 30 feet high, found in Georgia and Florida, and quite rare. It has been introduced into cultiration, and is hardy as far north as Philadelphia. When in bloom, it is beautiful, and it flowers continuously for two or three months.

\section{TILIACE A.}

The Tilias in Europe are called Lime trees, or Linn. Our species are commonly called Basswood. They are large trees, and have a wide range, being found probably in every State east of the Rocky Mountains. It is, however, not abundant, except in some localities. The wood is white and soft, and is employed to some extent in the manufacture of furniture, \&c.

No. 17. Tilia Americana, L.-Bässwood; Linden. Eastern United States.

No. 18. Tilia heterophylla, Vent._White Basswood. Eastern United States.

No. 19. Tilia pubescens, Ait.-White basswood. Eastern United States.

\section{ZYGOPHYLLACER.}

No. 20. Guaiacum sanctum, L.-Liguum Vitæ.-South Florida. A small tree, quite rare in South Florida, but common in the West Indies. It is very similar to, and has the same properties as the $G$. officinale of the West Indies, which furnishes the gum resin called guaiacum, which is a common stimulative aromatic medicine. The wood is much heavier than water. 


\section{ZANTHOXYLACEA.}

No. 21. Zanthoxylum A mericanum, Mill.-Prickly Ash; Toothache Tree. - Northeastern United States. A shrub or small tree. The bark is very hot and aromatic, and is somewhat used medicinally.

No. 22. Zanthoxylum Carolinianum, Lam.-Southern Prickly Ash.Southern States. A small tree found from South Carolina to Florida and westward. The bark is aromatic and tonic. The young stems are spiny, and the old ones more or less covered with tubercles, which hare dereloped from the spines.

No. 23. Zanthoxylum F'loridanum, Nutt.-Satin Wood.-South Florida.

No. 24. Zanthoxylum Pterota, H. B. K.-False Iron Wood; Yellow Wood.-The Gulf States. A small shrubby tree occurring from Florida to Texas. The wood is yellow and close-grained.

No. 25. Ptelea trifoliata, L.-Hop-tree.-Eastern United States. This is seldom more than a tall shrub. The fruit, a wafer-like seed, grows-in clusters, is a bitter tonic, and has been used as a substitute for hops.

No. 26. Ptelea angustifolia, Benth.-Narrower-leaved than the preceding.-Rocky Mountains; Texas to California.

\section{SimarubiaCe $A$.}

No. 27. Simaruba glauca, DC.-Quassia; Bitter-wood.-South Florida. Found in South Florida by Dr. Blodgett. It occurs in the West Indies with another species, the Simaruba amara, the bark of which is medicinal, and possesses the same properties as quassia.

\section{BURSER ACEA.}

No. 28. Bursera gummifera, Jacq.-West India Birch; Gummo Limbo.-Sonth Florida. The largest of South Florida trees, abounding in gum.

No. 29. Amyris Floridana, Nutt.-Torch Wood.-South Florida. Mostly a shrub, but becoming a small evergreen and elegant tree.

\section{OLACINEA.}

No. 30. Ximenia Americana, L.-Hog Plum.-South Florida. Mostly shrubby, but sometimes 20 feet high. It bears a drupe the size of a plum, which is yellow and pleasant-tasted.

\section{MeliaceA.}

No. 31. Melia Azederach, L.-Pride of India; Bread 'Tree.-Naturalized in Southern States. A native of Persia, but quite freely naturalized in some parts of the South. It is there one of the commonest ornamental trees. The wood is of a reddish color, solid, durable, and taking a beautiful finish.

\section{ILICINE AE.}

No. 32. Ilex opaca, Ait.-Evergreen Holly.-Southern States. In farorable localities, this tree attains a pretty large size, frequently 40 feet high, and 12 to 15 inches diameter. The wood is very heavy, compact, and fine-grained. It is employed in some parts of cabinet-work. It ver. closely resembles the European Holly.

No. 33. Ilex Dahoon, Walt.-Dahoon Holly.-Southern States.

-No. 34. Ilex decidua, Walt.-Deciduous Holly.-Southern States.

No. 35. Ilex monticola, Gr.-Holly.-Southern States. 


\section{Celastitine ai.}

No. 36. Schafferea frutescens, Jacq.-Crab-rood; False Box.-South Florida. A small tree of South Florida; the wood is close and finegrained, and is said to be exported from the West Indies as a kind of box-wood.

No. 37. Euonymus occidentalis, Nutt.-California Spindle Tree.-California.

No. 38. Euonymus atropurpureus, Jacq. - Waahoo. - Southern and Western States.

RHAMNACEA.

No. 39. Frangula Caroliniana, Gr.-Alder Buckthoru.-Virginia and outh ward.

No. 40. Frangula Purshiana, DC. - Oregon Buckthorn. - Western coast.

No. 41. Frangula Californica, Gr.-California Coffee-tree.-Western coast. This much resembles the $F$. Caroliniana. In California, the berries of this species have been employed to some extent as a substitute for coffee. Some persons recommend it; others have been made sick by its use.

No. 42. Ceanothus thyrsiflorus, Esch.-California Lilac. - Western coast. One of the most showy shrubs or small trees of California.

No. 43. Ceanothus divaricatus, Nutt.-California.

No. 44. Zizyphus obtusiflorus, Gr. - Texas Jujube-tree.-Texas and westward.

No. 45. Scutia ferrea, Brong.-Wouth Florida.

\section{SAPINDACEAE.}

No. 46. Aisculus glabra, Willd.-Ohio Buckeye-CTennessee and Western States. This tree attains, in favorable situatious, 20 to 30 feet height, and is much in use as an ornamental tree. It is not found wild east of the Alleghany Mountains; its favorable locality being the banks of the western rivers, in Ohio, Illinois, and Kentucky. The wood is light, soft, and useless. The nuts are said to be poisonous to cattle eating them.

No. 47. Asculus flava, Ait.-Sweet Buckeye.-Southern States. This tree prevails more to the southward than the Ohio Buckeye. It is abundant in the mountainous districts of North and South Carolina and Georgia. In favorable situations, it frequently attains a height of 50 to 60 feet, and the trunk a diameter of 2 to 3 feet. The flowers are of a light agreeable jellow and quite ornamental. The wood is soft and perishable.

No. 48. Assculus Pavia, L.-Red Buckeje.-Southern States. This species has nearly the same range as the preceding, but is usually only a shrub of 8 or 10 feet height; sometimes, however, becoming a smail tree.

No. 49. Assculus Californica, Nutt.-California Buckeye.-California. This is the only buckeye of the Pacific eoast. It forms a low, spreading, bushy tree from 15 to 20 feet high.

No. 50. Ungnadia speciosa, Endl._-Spanish Buckere.-Texas and westward. This is a large shrub or small tree, a native of Texas and New Mexico. The chestnut-like fruits have an agreeable, sweet taste, but are strongly emetic. The foliage resembles that of the hickory, (Carya.)

No. 51. Sapindus marginatus, Willd.-Soap Berry.-Southern States. This tree varies from 20 to 40 feet in height. It occurs along the coast 
in Georgia and Florida, also in Arkansas and Texas. The berries are smaller than those of the next species, but, like that, the black hard nuts of the berries are sometimes strung for beads and crosses.

No. 52. Sapindus Sapmaria, L.-White Wood.-South Florida. This species was found by Dr. Chapman in South Florida. In the West Indies, the berries and the roots are used as a substitute for soap. The berries are also used to intoxicate fish.

No. 53. Hypelate paniculata, Don.-Madeira Wood._-South Florida. A small tree found in South Florida. The wood is very like mahogany, and is highly valued.

No. 54. Acer saccharinum, Wang.-Sugar Maple; Hard Maple.-East. ern United States. The well-known Sugar Maple, from the sap of which in the Northern States and in Canada large quantities of sugar and sirup are made annually. It is one of the noblest of A merican trees, both for the value of its wood and the beauty of its form and foliage. It is much emplosed as an ornamental tree.

No. 55. Acer saccharinum, Wang., var. nigrum, Gr.-Black Sugar Maple.-Eastern United States. This variety differs little from the common form except in a darker wood.

No. 56. Acer dascycarpum, Ehrh.-Silver-leaf Maple.-Eastern United States. One of the most beantiful of maples; much used as a shadetree on account of its rapid growth and beautiful foliage.

No. 57. Acer rubrum, L.-Red Maple.-Eastern United States. More compact in form and less rapid in growth than the preceding, but, like it, a favorite for street-planting and ornament.

No. 58. Acer Pennsylvanicum, L.-Striped-bark Maple.-Northeastern United States. A small tree, the young bark with longitudinal stripes of green and black. Rare and little known outside of the Northeastern States.

No. 59. Acer macrophyllum, Pursh.-Oregon Maple.-California and Oregon. This occurs in the mountainous districts of California and Oregon. In Oregon, it attains a large size, and the wood abounds in that peculiarity of grain which is called Bird's-eye and Curled Maple. For cabinet purposes, it is thought to be equal to mahogany.

No. 60. Acer circinatum, Pursh.-Vine Maple.-Oregon and Washington Territory. This species has a low and frequently reclining or prostrate trunk, which sends forth branches, at first upright, then bending down to the ground, and forming almost impenetrable thickets.

No. 61. Acer grandidentatum, Nutt.-Great-toothed Maple.-California and Oregon. A small tree or shrub of the Rocky Mountains.

No. 62. Negundo aceroides, Moench.-Box Elder.-Eastern United States. This is a fine ornamental tree, of rapid growth, not commonly growing more than 20 to 30 feet high It is rare east of the Alleghanies, but found along all the rivers of the West, reaching into Kansas, Missouri, and Nebraska, and even northward into Minnesota and the British possessions. The sap contains a large amount of sugar. The wood is fine and close-grained, and has been used in cabinet-work.

No. 63. Negundo Californica, T. \& G.-California Box Elder.-California. This species is confined to the Pacific coast. It does not seem to differ greatly from the preceding species.

No. 64. Staphylea trifoliata, L.-Bladder Tree.-Eastern United States. A large shrub or small tree 10 to 15 feet high, with trifoliate leaves aud peculiar 3-lobed bladdery pods.

No. 65. Rhus typhina, L.-Staghorn Sumac.-Eastern United States. The Sumacs are large shrubs or small trees, mostly with pinnate leares. 
The leares and young twigs are employed in tanning, and are thought to be equal in strength to those of the Sicilian Sumac.

No. 66. Rhus glabra, L.-Smooth Sumac.-Eastern United States.

No. 67. Rhus microphylla, Eng.-Small-leared Sumac.-Texas and Southwest.

No. 68. Rhus copallina, L.-Dwarf Sumac.-Eastern United States.

No. 69. Rhus Metopium, L.-Coral Sumac.-South Florida. This grows in South Florida, where it attains a height of 20 to 30 feet. It is very poisonous. In the West Indies, it is called Mountain Manchineel and Burnwood.

No. 70. Rhus venenata, DC.-Poison Sumac.-Eastern United States.

No. 71. Rhus integrifolia, Nutt.-One-leaved Sumac.-South California. This species and the succeeding do not have pinuate leaves. They are found in Southern California. The red berries of this species are used by the Indians to make a cooling acid drink.

No. 72. Rhus Laurina, Nutt.-Laurel Sumac.-South California. A low spreading tree, much branched and very leafy, and exhaling to a considerable distance an aromatic odor. The flowers are somewhat showy, and the plant would be fine in cultivation.

No. 73. Pistacia Mexicana, H. B. K.-Mexican Pistacia-tree-CTexas.

No. 74. Schinus molle, L.-Pepper Tree.-Southwestern United States. Cultivated as an ornamental tree in California and in Mexico. It is probably introduced. The berries have the taste of black pepper.

\section{VITACE $\mathbb{A}$.}

No. 75. Titis cestivalis, Michx.-Summer Grape.-Eastern Uuited States.

No. 76. Vitis cordifolia, Michx.-Winter or Frost Grape.-Eastern United States.

\section{LEGUMIINOS AE.}

No. 77. Robinia Pseudocacia, L.-Common Locust.-Pennsylvania and southward. Hardly found north of the fortieth degree of latitude except in cultivation. It is chiefly found in the Alleghanies and the mountainous parts of Kentucky and Tennessee. It is a beautiful tree, attaining a height of 50 feet and upward. The wood is hard, compact, and very durable, much used in ship-building.

No. 78. Robinia viscosa, Vent.-Clammy Locust.-Virginia and southward. A smaller tree than the preceding, and much more rare, being confined to the mountains of Georgia and North Carolina.

No. 79. Robinia Neo.Mexicana, Gray.-New Mexican Locust.-New Mexico and Arizona. A small tree, rarely exceeding 20 feet. Very thorny. Grows in stony ravines at the foot of mountains in New Mexico and Arizona.

No. 80. Olneya tesota, Gray.-Palo de Hierro.-New Mexico and Arizona.

No. 81. Piscidia Erythrina, L.-Jamaica Dogwood.-South Florida. A tolerably large tree of South Florida; also grows in the West Indies. Its blossoms resemble those of the Locust. The wood is heavy, coarsegrained, and durable.

No. 82. Cladrastris tinctoria, Raf.-Yellow Wood.-Tennessee and Kentucky. This is one of the handsomest flowering-trees of the Locust kind. It grows chiefly in the mountainous regions of Kentucky and Tennessee. The wood is yellow, and has been used in domestic dyeing. 
The tree rarely exceeds 40 feet in height and 1 foot in diameter. It is well worthy of caltivation.

No. 83. Sophora affinis, T. \& G.-Texas and Southwest.

No. 84. Sophora speciosa, Benth.-Texas and Southwest. Our twc Sophoras are small trees of Texas and New Mexico, seldom over 6 inches in diameter. They produce an abundance of showy flowers very early in the season. The Sophora speciosa has evergreen leaves, and beautiful red beans, which are said to be poisonous.

No. 85. Gymnocladus Canadensis, Lam.-Kentucky Coffee-tree.-East. ern United States. A tall, large, and handsome tree, rare in Western New York, Pennsylvania, and the States north of the Ohio River; more common in Kentucky and southwestward. The wood is rery compact and close-grained, and valuable for cabinet-work. The large beans of the pods have been used for coffee.

No. 86. Gleditschia triacanthos, L.-Honey Locust.-Eastern United States. This is a large and handsome tree; the trunk and branches generally beset with long and formidable spines, on which account it has been employed as a hedge-plant. The long pods contain a sweetish pulp, and have been used in fermenting a kind of beer, but are of no practical value. The rood is heavy, and affords excellent fuel, but is not considered durable as a timber. The tree is rare in the Atlantic States, but rather common west of the Alleghanies, in Tennessee, Kentuck 5 , and the tributaries of the Ohio and Mississippi.

No. 87. Gleditschia monosperma, Walt.-Water Locust.-Illinois and southward. This is a smaller tree than the preceding, growing in swamps in the Southern States aud in the vicinity of the Ohio River. The pods are short, roundish, and only one-seeded. The tree is thorns, like the Honey Locust.

No. 88. Cercidium floridum, Benth.-Green-bark.-Western Texas and Arizona. This is the Palo Verdi of the Mexicans and the Green-barked Acacia of American travelers. The bark is smooth and green on the young trees. It is a small, wide-spreading tree, with many branches, rarely seen a foot through, and 20 to 30 feet high.

No. 89. Parkinsonia aculeata, L.-Jerusalem Thorn.-Western Texas and Arizona. Mostly a shrub; quite ornamental, and frequent in cultivation in the region bordering on Mexico.

No. 90. Parkinsonia microphylla, Torr.-Western Texas and Arizona.

No. 91. Cercis Canadensis, L. - Redbud or Judas Tree.-Eastern United States. The Redbuds are small trees; very ornamental. This species is frequent east of the Mississippi. The next is found principally on the Pacific coast.

No. 92. Cercis occidentalis, Torr.-Western Redbud.-Western United States.

No. 93. Prosopis glandulosa, T. \& G.-Mesquit.-Texas to California. A scrubby, small tree, seldom more than 25 to 30 feet high ; sometimes constituting extensive forests. It produces an abundance of bean-like pods, which contain a sweet pulp. Both beans and pulp are eaten by Indians and often by whites, but they are used chiefly as food for horses, which eat them with avidity. The wood is very hard and durable, dark brown, and resembles mahogany. Fences made of this timber are very durable. The wounded bark in spring exudes a gum of the same quality as gum arabic.

No. 94. Strombocarpus pubescens, Gr.-Screw-bean.-Texas and westward. This tree is very similar to the preceding, but of smaller size. The pods are two to three inches long, and twisted like a screw. They 
are eaten by the Colorado Indians, powdered to a coarse meal, and made into a kind of bread. They are also good food for horses.

No. 95. Lenccena retusa, Gr.-Texas and westward.

No. 96. Acacia Farnesiana, Willd.-Texas and westward.

No. 97. Pithecolobium Unguis-Cati, Benth.-Cat's-claw.-South Florida. In South Florida, mostly a shrub, rarely a small tree. The bark has medicinal properties.

\section{ROSACEA.}

No. 9S. Prunus Americana, Marsh.-Wild Yellow or Red Plum.-Eastern United States. This is the common wild plum of the country east of the Rocky Mountains, from Mississippi to Minnesota. In the valley of the Mississippi, and particularly southwestward, the two next named species also occur.

No. 99. Prunus rivularis, Scheele.-Wild Plum.-Mississippi Valley and westward.

No. 100. Prunus Chicasa, Michx.-Chickasaw Plum.-Southeastern United States.

No. 101. Prunus umbellata, Ell.-Small Wild Plum.--South Carolina and southward. A small purple or black plum, sour and bitter, growing from South Carolina to Florida.

No. 102. Prunus Pennsylvanica, L.-Wild Red Cherry.-Eastern United States. A small tree, or often a shrub, with sour, unpleasant fruit.

No. 103. Prunus serotina, Ehrh.-Wild Black Cherry.-Eastern United States. A fine, large tree, of wide range, frequent in the Northern and Western States, and along the Alleghany Mountains in the Southern States. The wood is compact, fine-grained, and highly esteemed for cabinet-work. The fruit is small, rather sweet and pleasant when fully ripe.

No. 104. Prunus Virginiana, L.-Choke-cherry-Eastern United States.

No. 105. Prunus Caroliniana, Ait.-Mock Orange.-North Carolina and southward. A small tree with evergreen leaves, growing from North Carolina to Florida and in the Gulf States. It closely resembles the Cherry Laurel of Europe. It is a beautiful tree for cultiration, but probably would not bear a northern climate.

No. 106. Prunus demissa, Walp.-Rocky Mountain Choke-cherry.Rocky Mountains and California.

No. 107. Prunus Andersonii, Gr.-Desert Plum.-California and Nerada.

No. 10S. Prunus ilicifolia, Nutt.-Holly-leared Cherry.-California.

No. 109. Prunus mollis, Doug.-Oregon. This is the principal wild cherry of Oregon and the northwestern coast. It grows to the height of 20 to 30 feet. The fruit is astringent and unpleasant.

No. 110. Nuttallia cerasiformis, T. \& G.-California.

No. 111. Adenostoma sparsiflora, Torr.-Chimisell.-Califoruia.

No. 112. Cercocarpus ledifolius, Nutt.-Mountain Mahogany.-Rocky Mountains. A low, spreading tree, not usually over 10 to 15 feet high, but sometimes 40 feet high, and $2 \frac{1}{2}$ feet thick. The leaves are evergreen; the wood is a dark red, like mahogany, extremely compact and heary. It is frequent on the mountains of Utah, Nevada, and California.

No. 11:3. Cercocarpus parvifolius, Nutt.-Small Mountain Mahogans.California. A much smaller tree or shrub than the preceding; the rood quite similar.

No. 114. Pyrus coronaria, L.-American Crab Apple.-Eastern United States. The common wild crab apple of the United States, growing in glades and frequently forming extensire thickets. The fruit is variable, 
but seldom palatable or serviceable. It is used, however, in new por tions of the country for preserves or for making cider.

No. 115. Pyrus angustifolia, Ait.-Narrow-leaved Crab.-Pennsylva. nia southward and westward. Perhaps only a rariety of the preceding, with narrower leaves and rather smaller fruit.

No. 116. Pyrus Americana, DC.-American Mountain Ash.-North. eastern United States. A small tree growing in swamps and mountain woods, sparingly in the Alleghany Mountains, most common in New England and northward. It is frequently seen in cultivation, and much resembles the European Mountaiu Ash. The clusters of bright-red berries are very ornamental, and remain on the tree until winter.

No. 117. Pyrus rivularis, Doug.-Oregon Crab Apple.-Oregon and Rocky Mountains. This is a small tree, ranging from California northward into Alaska. The fruit is of the size of a cherry, of an agreeable flavor, and used, particularly in Alaska, by the natives of the country for food.

No. 118. Cratagus spathulata, Michx.-Wild Thorn.-Virginia and southward. Of wild thorns, we have numerous species, most of which are small and shrubby. About twelve species and varieties of the country east of the Rocky Mountains may be counted as small trees, and two of the Rocky Mountains and western coast.

No. 119. Cratogus apiifolia, Michx.-Wild Thorn.-Virginia and southward.

No. 120. Cratcous cordata, Ait.-Washington Thorn.-Virginia and southward.

No. 121. Cratagus arborescens, Ell.-Wild Thorn.-Southern States.

No. 122. Cratcogus coccinea, L.--Scarlet-fruited Thorn.-Eastern United States.

No. 123. Cratcegus tomentosa, L.-Black or Pear Thorn.-Eastern United States.

No. 124. Cratagus tomentosa, L., var. punctata, Gr.-Black Thorn.Eastern United States.

No. 125. Cratcogus tomentosa, L., var. mollis, Gr.-Wild Thoru.-Eastern United States.

No. 126. Cratcgus Crus-galli, L.-Cockspur Thorn.-Eastern United States.

No. 127. Cratcous astivalis, T. \& G.-Wild Hawthorn.-Sonthern States.

No. 128. Cratcrgus flava, Ait.-Summer Haw.-Virginia and southward.

No. 129. Crategus glandulosa, Michx.-Wild Hawthorn._Virginia and sonthward.

No. 130. Cratcegus rivularis, Doug. - Western Hawthorn. - Rocky Mountains.

No. 131. Cratagus sanguinea, Pallas.-Oregon Thorn.-Oregon.

No. 132. Photinia arbutifolia, Lindl.-Laurel Hawthorn.-California. A beautiful evergreen shrub or small tree of the Pacific coast. It sometimes attains the height of 20 or 25 feet and a thickness of trunk of 12 or 15 inches.

No. 133. Amelanchier Canadensis, T. \& G.-Service or June Berrs.Eastern United States. Usually a small tree, but sometimes becoming 30 to 40 feet high, with a diameter of 10 or 12 inches. It is found mostly by the banks of mountain-streams. There are several varieties.

No. 134. Amelanchier alnifolius, Nutt.-Service Berry.-Rocky Mountains. This is usually a shrub; in Oregon and Washington Territory, it is said to be a small tree, yielding abundance of berries, which are largely employed as food by the Indians. 


\section{HAMAMELACE $A$.}

No. 135. Liquidambar styraciflua, L.-Sweet Gum or Bilsterd-Eastern United States. A large and beantiful tree, with singular star-like leaves, somewhat resembling the maple. It grows in the Atlantic States in rich, low woods; also in the Mississippi Valley, but not far north of the Ohio. The wood is compact and fine-grained, but not durable. It is a fine ornamental tree, and deserving of cultivation.

\section{RHIZOPHORACE AE.}

No. 136. Rhisophora Mangle, L. - Red Mangrove. - South Florida. Commonly a low, spreading tree in South Florida, also in Louisiana and on the coast of Texas. On the Thousand Islands, it attains a height of 40 to 60 feet. All the low keys along the coast are covered by this tree. It sends down roots from its germinating fruits, which take root upon reaching the earth, and thus forms an impenetrable thicket like the Banyan tree of India.

Combretacha.

No. 137. Conocarpus erecta, Jacq.-White Button Wood.-Florida. A small tree of the West Indies and South Florida. It furnishes almost the only fuel used in South Florida, and extends north as far as Ancelote Keys.-(Dr. Chapman.)

No. 138. Laguncularia racemosa, Gært.-Black Button Wood.-South Florida. Found by Dr. Chapman in South Florida; a small tree everywhere; is a mere shrub, except among the Thousand Islands and north of Cape Sable, where it forms a large tree.

\section{MYRTACEA.}

No. 139. Eugenia buxifolia, Willd.-Iron Wood.-South Florida. The Eugenias are in Florida small trees, reaching 20 to 25 feet in beight. They belong to the Myrtle family, and the flowers of some species are rery fragrant. The wood is close-grained, hard, and applicable to cabinet-work.

No.140. Eugenia monticola, DC.-Iron Wood.-_South Florida.

No. 141. Eugenia procera, Poir.-Iron Wood.-South Florida.

No. 142. Eugenia dichotoma, DC.-Stopper Wood.-South Florida.

No. 143. Psidium pyriforme, L.-Guava.-South Florida. The Guava is a well-known fruit in the West Indies, where it is highly esteemed, and eaten either raw or formed into preserves. Dr. Chapman found the tree extensively naturalized at Tampa Bay, Florida.

\section{Cactacen.}

No. 144. Cercus giganteus, Eng.--Tree Cactus.-Western Texas and Arizona. The specimens for this order are from Southern Arizona, where they are striking and characteristic features of the country. The Cereus giganteus grows 50 to 60 feet in a straight column, and finally divides into several naked-looking branches. The wood of this and other large Cacti presents a singular net-work of fibers in distinct lajers.

No. 145. Cereus Thurberi, Eng.-Thurber's Cactus.-Western Texas and Arizona.

No. 146. Opuntia arborescens, Eng.-Tree Opuntia._-Western Texas and Arizona. 
ARALIACEA.

No. 147. Aralia spinosa, L.-Angelica Tree or Hercules's Club.-Eastern United States.

CORNACE.E.

No. 148. Cornus florida, L.-Flowering Dogwood.--Eastern Uniter States. This is usually a small tree, but sometimes acquires a height of 40 or 50 feet, and a diameter of trunk of $1 \frac{1}{2}$ feet. It flowers in spring before the full development of the leaves, and then presents a beautiful appearance. It deserves to be more generally cultivated.

No. 149. Cornus Nuttallii, Aud.-White Dogwood.-California and Oregon. This species, which is confined to the Pacific coast, has rather larger:flowers than the preceding, and is perhaps more showy. The wood of both is hard and valuable. Grows sometimes 50 or 60 feet high.

No. 150. Cornus pubescens, Nutt.-Western Dogwood.-California and Oregon. This rarely becomes a small tree, 25 to 30 feet high, on the Pacific coast. We have five or six other species of dogwood which do not attain tree size.

No. 151. Garrya Fremontii, Torr.-Tassel-tree-Oregon and California. The Garryas are mostly shrubs, though under favorable circumstances the Garrya elliptica gains a height of 20 to 30 feet.

No. 152. Garrya elliptica, Lindl.-Satin Tassel-tree.-California.

No. 153. Nyssa multiflora, Wang.-Black or Sour Gum; Pepperidge.Eastern United States. A middle-sized tree, growing from Massachusetts to Illinois and southward. The fibers of the wood are so interwoven that it is almost impossible to split it; hence it is used for wheelhubs, rollers, and cylinders.-(Bryant.) It is quite ornamental in cultivation.

No.154. Nyssa aquatica, L.-Water Tupelo.-Southern States. This species grows in low wet ground, chiefly in the Southern States, but is found also in New Jersey and Pennsylvania. The wood is very tough, and has been used in the manufacture of wooden bowls, \&c.

No. 155. Nyssa uniflora, Walt.-Large Tupelo.-Virginia and southward. This is the largest tree of the genus. It is confined to the Southern States, growing in swamps. It bears a dark-blue plum-like fruit nearly an inch long. The wood is soft and extremely light. The roots are also extremely light and soft, and have been used as a substitute for cork. The wood is only used to make bowls and trays.

No. 156. Nyssa capitata, Walt.-Ogeechee Lime.-Sonthern Uniter States. This species is found in swamps in Georgia and Florida and westward near the coast. It bears an oblong red plum-like fruit, which is agreeably acid; and can be employed as a substitute for the lemon. The tree is small and the wood without value.

\section{Caprifoliace $A$ e.}

No. 157. Sambucus glauca, Nutt.-California Elder.-California and Rocky Mountains. This species of elder in California forms a low tree, sometimes 30 feet high, with a stem 2 feet in diameter. Indians and birds eat the berries.

No. 158. Viburnum prunifolium, L.-Black Haw.-Eastern United States. The haws are small trees or large shrubs, with smooth glossy leaves and handsome flowers. They are worthy of cultivation.

No. 159. Viburnum Lentago, L.-Sweet Viburnum or Sheepberry.Eastern United States.

No. 160. Viburnum obovatum, Walt.-Wild Haw.-Virginia and south. ward. 


\section{RUBIACEA.}

No. 161. Cephalanthus occidentalis, L., var. Californica.-Button-bush. -California. This is seldom more than a shrub; but in California it sometimes grows 25 to 30 feet high, with a trunk 12 to 20 inches in diam. eter.

No. 162. Guettarda Blodgettii, Suttle.-South Florida.

No. 163. Randia clusiafolia, Chap.-Seven-years Apple.-South Florida.

No. 164. Pinckneya pubens, Michx.-Georgia Bark.-Sonth Carolina to Florida. A small tree in the lower districts of Georgia and in Florida, rarely exceeding the height of 25 feet and a diameter of 6 inches. The bark is extremely bitter, and has been employed in the treatment of intermittent fevers. It is closely related botanically to the Cinchona, which furnishes the Peruvian bark of commerce.

\section{ERICACE A.}

No. 165. Vaccinium arboreum, Marshall.-Farkleberry.-Virginia and southward. A shrub or small tree sometimes 20 feet high, growing from Virginia and Southern Illinois south ward.

No. 166. Oxydendrum arboreum, DC.-Sourwood or Sorrel-tree.Pennsylvania and southward. This tree grows chiefly in the mountainous districts of the Alleghanies from Pennsylvania southward. In fertile valleys, at the foot of the mountains, in North Carolina and Tennessee, it attains a height of 50 feet. The common name sour-tree is derived from the acidity of its leaves. The flowers are white, and in spikes 5 or 6 inches long. They are very ornamental, and begin to be produced when the tree is 5 or 6 feet high.

No. 167. Kálmia latifolia, L.-Calico-bush or Mountain Laurel.-Pennsylvania and southward. A beautiful evergreen shrub, sometimes attaining the size of a small tree. It is very ornamental and deserving of cultivation.

No. 168. Rhododendron maximum, L.-Rose Bay or Great Laurel.Pennsylvania and southward. Like the preceding, an evergreeu shrub of great beauty. It has been much improved by cultivation.

No. 169. Rhododendron Californicum, Hook.-California Rhododendron.-Pacific coast.

No.170. Arbutus Menziesii, Pursh.-Madrone-tree.-California and Oregon.

No. 171. Arbutus Texana.-This species or variety grows in Texas. It is mostly a large shrub; sometimes, horrerer, becoming 25 feet high and 8 or 10 inches in diameter. The leaves are smaller and the flowers less panicled than in the California species. The timber is said to be almost imperishable.

No. 172. Arctostaphylos glauca, Lindl.-Manzanita.-Oregon and California. There are several species of this genus on the western coast, mostly shrubs or small trees, which bave been much confused. The specimen under this number is from Southern California, and has a large drupe-like fruit, with a consolidated nut. These berries are pleasant to the taste, and much employed as food by the Indians of that region.

No. 173. Arctostaphylos tomentosa, Doug.-NIanzanita.-California and Rocky Mountains.

No. 174. Arctostaphylos pungens, H. B. K.-Manzauita.-Ca'ifornia and Rocky Mountains. 


\section{STYRACACE $A$.}

No. 175. Halesia diptera, L.-Snowdrop-tree.-Georgia and Florida. The Snowdrop-trees are found in the Southern States from the Ohio River southward, near the Alleghanies, and on river-banks in Georgia and Florida. They are usually smallish trees, but sometimes grow 40 or 50 feet high, and $1 \frac{1}{2}$ to 2 feet in diameter. They are very desirable for ornamental trees, producing a profusion of white bell-shaped flowers, even when quite small.

No. 176. Halesia tetraptera, L.-Silverbell-tree.-Virginia and Southward.

No. 177. Symplocos tinctoria, L'Her-_Horse Sugar or Sweet-leaf.-Virginia and southward. A small tree with oblong evergreen leaves, and clustered racemes of small white flowers. It grows in low, damp woods and pine barrens in North Carolina, Georgia, and Florida, and attains a height of 12 to 20 feet, with a diameter of 8 to 10 inches. It is one of the nost beautiful trees of the southern forest.-(Nuttall.)

\section{Cyrillace $A$ e.}

No. 178. Cyrilla racemiflora, Walt.-Iron-wood.-North Caroliua and southward.

No. 179. Cliftonia ligustrina, Banks.-Buckwheat-tree.-Georgia and southward. An elegant small tree, growing from 10 to 20 feet high, of about the same range as the preceding. It is evergreen, and exceed. ingly oruamental when in flower. After flowering, the tree presents a curious appearance, from the abundance of triangular winged capsules, resembling buckwheat, from which the treereceives its popular name.

\section{EBENACE AE.}

No. 180. Diospyros Virginiana, L.-Persimmon.-Eastern United States. A well-known tree, most common in the Southern States, but growing as far north as New York. It grows from 30 to 60 feet high, with a very hard fine.grained wood, which has been used for various purposes. It bears a plum-like fruit an inch or more in lengtl, which when fully ripe is edible and palatable.

No. 181. Diospyros Texana, Schul.-Black Persimmon.-Western Texas. This is called Sapote-pieto by the Mexicans and Black Persim. mon by the Americans. It is a shrub or middle-sized tree, often with a black, ebony-like core. The fruits are black, and of the size of a cherry and larger, melting, and very sweet.-(Dr. Lindheimer.)

\section{SAPOTACE AE.}

No. 182. Sideroxylon pallidum, Spreng.-Mastic.-South Florida. A middle-sized tree of South Florida called Mastic, probably from the production of a gum resembling mastic.

No. 183. Dipholis salicifolia, A. D C.-South Florida.

No. 184. Chrysophyllum microphyllum, Jacq.-Golden-leaf.-South Florida. A small tree of the West Indies, found by Dr. Chapman last fall in South Florida. The leares have a beautiful, golden, satin-like surface on the under side.-

No. 185. Mimusops Sieberi, A. DC. - Naseberr5. - South Florida. This is one of the trees called Naseberry in the West Indies. It is common in South Florida, where it becomes a large tree. Dr. Chapman 
invariably found the large trunks to be hollow. The fruit is delicious and highly flavored.

No. 186. Bumelia lycioides, Grert.-Iron-wood.-Kentucky and southwarl. The Bumelias are shrubs or small trees, of no special value.

No. 187. Bumelia parvifolia, A. D C.-Iron-wood.-South Florida.

No. 138. Bumelia lanuginosa, Pers.-Iron-wood.-Southern States.

No. 189. Bumelia tenax, Willd._Iron-Wood.-Southern States.

No. 190. Bumelia reclinata, Vent.-Irou-wood.-Texas and westward.

\section{THEOPHRASTACEAE.}

No.191. Jacquinia armillaris, L.-Currant-trees.-South Florida, A small tree of South Florida and the West Indies. The rood is curiously grained.

MrRSINACE AE.

No. 192. Myrsine Floridana, A. DC.-South Florida.-Mostly a shrub, rarely a small tree.

No. 193. Ardisia Pickeringii, T. \& G.-South Florida.-Mostl 5 a shrub, but on the keys a small tree. It is an evergreen tree, with laurel-like leares, and panicles of show $y$-white purple-tinged flowers.

\section{BignoniaCE A.}

No. 194. Catalpa bignonioides, Walt.-Catalpa.-Southeru States. A tree well known in cultivation, and hardy as far north as latitude $41{ }^{\circ}$. It is native in the Southern and Southwestern States and in Southern Illinois and Indiana. It attains a height of 50 or 60 feet, and a diameter of $1 \frac{1}{2}$ to 2 feet. The leaves are large, and the flowers showy, and when in bloom the tree is extremely ornamental. The wood is light, but of a fine texture, and capable of receiving a fine polish. It is said to be very durable.

No. 195. Chilopsis linearis, DC.-Texas and Arizona. Usually a shrub, but sometimes attaining a height of 25 feet. It has long willowlike leaves, and is very ornamental when in flower.

No. 196. Tecoma radicans. Juss.-Trumpet-vine.-Southern States. This beantiful woody vine sometimes acquires a woody trunk of a foot in diameter or more.

\section{VERBENACE A.}

No. 197. Citharexylum villosum, Jacq.-Fiddle-wood.-South Florida. Rarely a small tree, of no economic value.

No. 198. Avicennia tomentosa, Jacq.-Black Mangrore.-South Florida. This and the next species are called Black Mangrove, obserred by Dr. Chapman at Cedar Keys and the Thousand Islands. They are low evergreen trees, forming impenetrable thickets on the muddy shores of the sea.

No. 199. Avicennia oblongifolia, Chap.-Black Mangrove.-South Florida.

\section{Order BorraginaCe $A$.}

No. 200. Cardia bullata, L.-South Florida.

No. 201. Ehretia Buerreria, L.-South Florida.

No. 202. Ehretia elliptica.-Texas.-Mostly shrubby, but sometimes a tree 2 feet in diameter; fruit an orange-Jellow berry, of the size of a pea; much liked by children and birds. The evergreen rough leares are used to rub and destroy eruptions of the skin.-(Dr. Lindheimer.) 


\section{OLEACEA.}

No. 203. Olea Americana, L.-Devil-wood; American Olire.-Southern States. This is a small evergreen tree, with thick, leathery leaves, and small, white, fragrant flowers. It is related to the olive-tree of the eastern world, but its fruit has no value. It is impossible to split, and hence the vulgar name of Devil-wood.

No.204. Chionanthus Virginica, L.-Fringe-tree.-Middle and Sontlern States.

No.205. Fraxinus Americana, L.-White Ash.--Eastern United States. A large and valuable tree ranging over the eastern portion of the United States. The wood is tough and elastic, and much employed in various manufactures. It is a handsome and ornamental tree.

No.206. Fraxinus pubescens, Lam.-Red Ash.-Eastern United States. A smaller tree than the preceding, perhaps more common. The wood is said to be equally as valuable as that of the White Ash.

No. 207. Fraxinus viridis, Michx.-Green Ash.-Western States. A middle-sized tree, of vigorous and rapid growth, and the wood has the same qualities as the preceding.

No. 208. Fraxinus sambucifolia, Lam.-Black Ash.-Northern and Western States. A large tree, usually growing in moist soil, and hence often called Swamp Ash. The wood is more elastic than that of any other species. It splits easily into thin, narrow strips, which are used for making baskets and hoops for barrels.

No. 209. Fraxinus quadrangulata, Michx.-Blue Ash.-Western Statès. This species is not found in the Atlantic States. It is found from Ohio to Wisconsin and southward to Kentucky and Temnessee. It is a large tree, growing from 60 to 70 feet high, with a diameter of 2 feet or more. The wood is quite as valuable as that of the White Ash, and is said to be much more durable when exposed to the weather; hence its value for fence-rails, posts, \&c.

No. 210. Fraxiuus platycarpa, Michx.-Carolina Water Ash.-Southern States. This species grows in swamps or marshy banks of rivers. It is usually 25 or 30 feet high, but sometimes becomes a large tree. The wood is remarkably light and soft, and probably has no economic ralue.

No. 211. Fraxinus Curtissi, n. sp.?-Southern States. Mr. Curtiss found at Eufaula, Ala., a large ash with remarkably small fruit. This species is provisionally called $F$. Curtissi. It requires further investigation.

No. 212. Fraximus Oregona, Nutt.-Oregon Ash.-California and Oregon. The common ash of the Pacific coast. It grows 60 to 70 feet high. Is of equal value with the W'hite Ash of the Eastern States.

No. 213. Fraxinus dipetala, H. and A.-California Flowering Ash.California and Oregon.

No. 214. Fraxinus pistaciafolia, Torr.-Texas and westward.

No. 215. Fraxinus anomala, Torr.-Single-leaf Ash.-Utah and Arizona. This ash is seldom more than a shrub 10 to 15 feet high, growing in ravines among the foot-hills of Southern Utah and Arizona. The leaves are simple, not pinnate, as in the other species.

No. 216. Fraxinus coriacea, Watson.-Thick-leaved Ash.-Utah and Arizona. A smallish tree, with thick, leathery leaves, growing in Southern Utah and Arizona.

No. 217. Forestiera acuminata, Poir.-Southwestern States.-A large shrub or small tree, of no economic value.

No. 218. Forestiera ligustrina, Poir.-Southern States. 


\section{NYCTAGENIACEA.}

No. 219. Poisonia obtusata, Swartz.-South Florida. A small tree of Florida and the West Indies.

\section{Polygonace A.}

No. 220. Coccoloba uvifera, Jacq.-Sea-side Grape.-South Florida. This and the following species are low and spreading trees, along the coast in Florida and the West Indies. It is remarkable for the grapelike clusters of pear-shaped purple berries, which have an agreeable subacid taste, and which are much employed. The wood is heary, hard, and valuable for cabinet-work.

No. 221. Coccoloba Floridana, Meisner.-Sea-side Grape.-South Florida.

\section{LAURACE A.}

No. 222. Persea Carnlinensis, Nées.-Red Bay.-Southern States. This species occurs from Southern Virginia to Florida and the Gulf States. It is found in the vicinity of swamps and swampy river-borders. In favorable situations, it grows to 50 or 60 feet high and 15 to 20 inches in diameter. The leares are large, shining, and erergreen. The wood is of a beautiful rose-color, of a fine, compact grain, and finishes almost equal to mahogans.

No. 223. P'ersea Catesbyana, Chap.-Catesby's Bay.-South Florida.

No. 224. Sassafras officinale, Nées.-Sassafras.-Eastern United States. This tree is found over a large portion of the United States. It is usually a small tree, but sometimes attains a large size. The wood is not rery strong, but is fine-grained and durable. It is valuable for cabinetwork. The bark of the root has a spicy, aromatic taste, and has some reputation as a medicine.

No. 225. Oreodaphne Californica.-California Myrtle.-California and Oregon. The California Laurel is a fine ornamental evergreen tree, growing in open places from 50 to 60 feet high. In thick woods, it has been found shooting up to 100 or 120 feet. The leaves have a very pungent odor, which produces headache in some persons. The rood is very beautiful, and is used for fine cabinet-work.

\section{Eleagnace A.}

No. 226. Shepherdia argentea.-Buffalo-berry.-Rocky Mountains. A large shrub or small tree, growing in thickets on the banks of streams in the Rocky Mountain valleys. The scarlet berries have an agreeable taste, and are employed as food by the natives.

\section{EUPHORBIACE AE.}

No. 227. Hippomane Mancinella, L.-Manchineel._South Florida.

No. 228. Stillingia sebifera, Michx.-Tallow-tree.-Naturalized in the Southern States. The Tallow-tree is a native of China, but has become extensicely naturalized in the East and West Indies, and also in sev. eral of the Southern States along the sea-const. In its natire country, its seeds and pods are bruised and then boiled, which causes a kind of tallow to rise to the surface. This tallow is much employed in making candles.

No. 229.-Excocaria lucida, Swartz.-Poison-wood.-Sonth Florida. 
No. 230. Drypetes crocea, Poir.-A small tree of South Florida and the West Indies. The leares are evergreen, and have muchthe flaror of tea. No. 231. Drypetes glauca, Vahl.-South Florida.

\section{URTICACEA. .}

No. 232. Morus rubra, L.-Red Mulberry.-Eastern United States. The Red Mulberry is found throughout the greater part of the United States east of the Mississippi, and also in some of the States west of that river.-(Bryant.) It is commonly a smallish tree, sometimes, however, attaining a large size. The berries are quite palatable, are eaten eagerly by birds, and also have a place in the markets as a second-rate fruit. The wood is strong, compact, and extremely durable.

No. 233. Morus parvifolia, Buck.-Small-leaved Mulberry.-Texas and westward.

No. 234. Maclura aurantiaca, Nutt.-Osage Orange.-Arkansas and Southwest. This tree, which is native in Arkansas and Texas, has been quite generally introduced over the country, chiefly from its extensice employment as a hedge-plant. The early French settlers called it Bois d'arc, or Bow-wood, from its use by the Indians for bows. The fruit is of the size and color of a large orange, but is not edible. The wood is very hard, elastic, fine-grained, and durable.

No. 235. Ficus aurea, Nutt.-Gum-tree; Wild Fig.-South Florida. There are many species of wild fig in the West Indies, but this species of South Florida has not been identified with any of them. It is a large tree, full of milky juice, which forms a kind of India rubber, whence it is also called Gum-tree. The fruit is very small and insignificant.

No. 236. Ficus pedunculata, Willd.-Wild Fig.-South Florida. This tree is also a native of the West Indies, and, like the Banyan of the West Indies, it sends downward aërial roots, which become fixed in the soil. The fruit is larger than the preceding, being the size of a large cherry.

No.237. Ficus brevifolia, Nutt.-Wild Fig.-South Florida.

No. 238. Ulmus Americana, L.-White Elm.-Eastern United States. One of our most common and valuable trees, very popular as a shadetree on account of its graceful form. It is one of the largest of the deciduous trees of the United States, attaining sometimes the height of 100 feet. The wood is employed for various purposes, but it is not considered durable when exposed to the weather.

No. 239. Ulmus fulva, Michx.-Slippery Elm.-Eastern United States. This is usually a smaller tree than the White Elm. It is not as much esteemed as an ornamental tree. The wood, however, is said to be of better quality and more durable. The inner bark is rery mucilaginous, and is in extensire use for medical and surgical purposes.

No. 240. Ulmus racemosa, Thomas.-Corky White Elm.-Northern States. This tree is limited to the northern portions of the United States, being found sparingly in New England, New York, and westward to northern Illinois and Wisconsin. It closely resembles the White Elm, but may be distinguished by the corky wings of the smaller branches, which cause them to look grotesque and rough. Dr. S. H. Wright, of Penn Yan, N. Y., says it grows as rapidly as the White Elm, and he thinks will become as large. He has seen some joung trees over two feet in diameter. The wood is tougher and finer-grained than the White Elm.

No. 241. Ulmus alata, Michx.-Winged Elm.-Southern and Western 
States. This species does not grow in the Northern States except on the line of the Ohio River. It is a smallish tree, and has smaller leaves than the other kinds. The branches have a broad and thin corky wing on the opposite sides. The wood is finer-grained and more compact than the White Elm.

No. 242. Ulmus Floridana, Chap.-Florida Elm.-Florida.

No. 243. Ulmus crassifolia, Nutt.-Thick-leaved Elm.-Texas and Southwest.

No. 244. Planera aquatica, Gmel--Planer-tree--Southern States. This tree is found in the Southern States and in Kentucky and Tennessee. It is a tree of medium size, with foliage somewhat like that of the European Elm. It is not a common tree, and the wood is not known to be applied to any useful purpose.

No. 245. Celtis occidentalis, L.-Sugar or Hackberry.-Eastern United States. This tree is rare in the New England States, but rather common in the southern and western ones. There are sereral varieties, one of which is usually a low and straggling bush. In the Western States, it often becomes a lofty tree. It somewhat resembles the elm in foliage and the ash in bark. It produces a dryish kind of berry about the size of a pea. The wood is white, but is not considered durable.

No. 246. Celtis Mississippiensis, Bosc.-Mississippi Hackberry.-Mississippi Valley.

No. 247. Celtis reticulata, Torr.-Net-leaved Hackberry.-Texas and Sonthwest. This is a western species, occuring in Texas and the Rocky Nountain region. It is a small tree, often a mere shrub.

No. 248. Celtis pallida, Torr.-Pale-leared Hackberry.-Texas.

Platanacex.

No. 249. Platanus occidentalis, I.--Sycamore; Plane-tree.-Eastern United States. This is probabls the largest deciduous tree in the United States. It occurs throughout the Eastern, Southern, and Western States, and extends berond the Mississippi Rirer. In the rich bottomlands of the western rivers, it sometimes attains the enormous circumference of 40 to 45 feet. It much resembles the European Plane-tree, and is thought to possess a richer foliage, and to afford a deeper shade. As a timber-tree it is of little value, as the wood is liable to warp, and decays early.

No. 250. Platanus racemosa, Nutt.-California Sycamore-California. This is the sycamore of the Pacific coast, extending from Central California to Mexico. Although a large tree, it does not attain the size of the eastern species. The wood is said to be more valuable, receiving a good polish and being more durable.

No. 251. Platanus Wrightiana, S. W.-Wright's Sycamore.-Arizona

\section{JUGLANDACEX.}

No. 252. Juglans nigra, L.-Black Walnut.-Eastern United States. This tree occurs in the Atlantic States, but attains its greatest perfection and abundance in the ralleys of the Ohio and Mississippi. It has been so much in request for the timber that it is much less common than formerly. The wood is used for the inside finish of houses, for cabinet. work, for gun-stocks, and many other purposes. It produees a nut much like the English walnut, but of stronger oily flaror. They are greatly relished by many persons.

No. 253. Juglans cinerea, L.-Butternut; White Walnut.-Eastern 
United States. This is more limited in range than the precediug. In Pennsylvania, New York, and New England, it probably attains its greatest perfection. It is a smaller tree than the Black Walnut. It is also found in the Western States. The wood is of a light-brown color, fine-grained, and easily worked. Although less valuable than the Black Walnut, the wood is well adapted to many uses. The nuts are not as highly esteemed as those of the Black Walnut.

No. 254. Juglans Californica, S. W.-Califoruia Walnut.-California. The California Walnut attains, in favorable situations, a height of 50 to 75 feet, and a diameter of 2 to 3 feet. It does not seem to be abunlant, and we know nothing respecting the value of its wood. It has recently been distinguished as a different species from the walnut of Arizona and New Mexico.

No. 255. Juglans rupestris, Eng.-Small Black Walnut.-Texas and Arizona.

No. 256. Carya oliveformis, Nutt.-Pecan-nut.-Mississippi Valley. This tree grows in the valley of the Mississippi and its tributaries, on the Arkansas, the Missouri, the Illinois, the Wabash, and the Ohio, for some two hundred miles above its mouth. The wood is coarse-grained, heavy, and compact. It is a beautiful tree, with a straight and wellshaped trunk. The nut is well known in the markets, and is thought by some to be superior in flavor to any other nut known.

No. 257. Carya alba, Nutt._Shell-bark Hickory.-Eastern United States. This species becomes a lofty tree, 80 feet high, with a diameter sometimes of 2 feet. It is one of the most valuable of the bickories for timber and for fuel. It furnishes most of the hickory-nuts of commerce. They are pleasant-flavored and highly esteemed. On large trees, the bark shells off in long narrow plates, whence the common name of the tree. The wood is heavy, elastic, and strong, and for handles of axes and agricultural implements, and many other uses, it is unequaled. T'here is little difference in the quality and value of many of the different species of hickory.

No. 258. Carya sulcata, Nutt.-Western Shell-bark.-Western States.

No. 259. Carya tomentosa, Nutt.-Mocker-Nut.-Eastern United States.

No. 260. Carya amara, Nutt.-Bitter-nut.-Eastern United States. This is a large tree, growing from 60 to 70 feet high. The timber is said to be inferior to the preceding species, and the nuts are thin-shelled bitter, and worthless.

No. 261. Carya porcina, Nutt.-Pig-nut Hickory.-Eastern United States. A large tree, with ismall pear-shaped fruit, the nuts bitterish and unpalatable. The wood is tough and valuable.

No. 262. Carya microcarpa, Nutt.-Small-fruited Hickory.-Eastern United States.

No. 263. Carya myristicaformis, Michx.-Nutmeg Hickory.-Southern States. This species grows in swamps in the Southern States. The fruit resembles a nutmeg, whence the name of Nutmeg Hickory. It is somewhat like that of the Bitter-nut tree, but much thicker.

No. 264. Carya aquatica, Nutt.-Swamp Hickory.-Southern States. A species growing in swamps in the Southern States, with astringent, bitter fruit, and brittle, worthless timber.

\section{CUPULIFER A.}

No. 265. Quercus macrocarpa, Michx -Bur Oak Orercup Oak.Western States This species is rare in the Eastern States, but com- 
mon in Michigan, Illinois, Wisconsin, and Minnesota. It is a large tree, and when growing on low ground assumes a rounded and handsome form. It has very large acorns, which are usually deeply immersed in the cup; the border of the cup fringed with loose scales The wood is open and brittle as it occurs in the prairie country, but valuable for fuel.

No. 266. Quercus alba, L.-White Oak.-Eastern United States. This is one of the noblest, largest, and most useful oaks of this country. The wood is strong, compact, and durable, and is only second to that of the Live Oak. It is extensively employed in ship.building, in manufacturing, and for many purposes.

No. 267. Quercus lyrata, Walt.-Southern Overcup Oak.-Southern States. This much resembles the Bur Oak, but is chiefly confined to the Southern States.

No. 268. Quercus stellata, Wang._Post Oak._Wastern United States. This species grows mostly upon poor clay lands. It is a middle-sized tree; the wood is yellowish, strong, fine-grained, and more durable than the White Oak.

No. 269. Quercus bicolor, Willd.-Swamp White Oak.-Eastern United States.

No. 270. Quercus Michauxii, Nutt. - Michaux's Oak.-Southeastern United States.

No. 271. Quercus Prinus, L.-Chestnut Oak.-Eastern United States. Of this species there are sereral varieties. It is usually a large and lofty tree. Its timber is inferior to that of the White Oak in strength, but is still very valuable for many uses.

No. 272. Quercus Prinus, L., var. monticola, Michx.-Rock Chestnut Oak.-New England and Middle States.

No. 273. Quercus Prinus, L., var. acuminata, Michx.-Yellow Chestunt Oak.-Northern and Western States.

No. 274. Quercus Douglasii, Hook. \& Am.-Douglas's Oak.-Rocky Mountains and California. This and the next two succeeding species are the California White Oaks, extending into Oregon and Columbia. They are probably of equal value with the eastern species.

No. 275. Quercus Garryana, Hook.-Garry's Oak. - California and Oregon.

No. 276. Quercus lobata, Nées--California White Oak.-California.

No. 27\%. Quercus undulata, Torr. - Rocky Mountain Oak.-Rocky Mountains. This is the common oak of the Rocky Mountains, usually small and scrubby, but sometimes forming a moderate sized tree. It is very variable in the foliage.

No. 278. Quercus densiflora, Hook. \& Am.-California Tau-bark Oak.California. This is an anomalous species of California, between an oak and a chestnut. In open ground, it is a beautiful, spreading, prramidal tree, with a trunk sometimes 5 to 6 feet in diameter. Amoug the foresttrees, it rises to 100 feet or more in height.

No. 279. Quercus agrifolia, Nées.-California Field Oak.-California. This is commonly kuown in California as Erergreen Oak. It grows usually in open grounds, with a wide, spreading, apple-tree-like top. It is usually a small tree, sometimes a mere shrub, and occasionally becoming 40 or 50 feet high.

No. 280. Quercus chrysolepis, Liebm.-Cañon Live Oak.-California. An erergreen oak, growing in rocky cañons and on mountain-sides. It is sometimes shrubby; sometimes like the last, becoming 40 or 50 feet high. It furnishes the hardest oak-wood of the Pacific coast, and is used in making ox·bows, ax-handles, \&c. 
No. 281. Quercus oblongifolia, Torr._Oblong-leaved Oak.-A rizona and California.

No. 282. Quercus Emoryi, Torr.-Emory's Oak.-Arizona.

No. 283. Quercus hypoleuca, Eng.-New Mexican Oak.-Arizona.

No. 284. Quercus Durandii, Buckly.-Durand's Oak.-Texas. This species approaches the Post Oak in general characters. The leares are variable, being sometimes lobed, and sometimes entire.

No. 285. Quercus Phellos, L.-Willow Oak.-Southern States. This species is confined to the States bordering the Atlantic and the Gulf; not, howerer, extending into the New England States. It is remarkable for its narrow, willow-shaped leares. The wood is strong, but coarsegrained, and not durable.

No. 286. Quercus virens, Ait.-Live Uak.-Southern States. This is the famous Live Oak. It grows from Southern Virginia to Florida and westward in the vicinity of the sea-coast. The wood is more esteemed for ship-building than any other. It is evergreen, and is a large tree, with spreading branches.

No. 287. Quercus cinerea, Michx.-Upland Willow Oak.-Southern States. A small tree, growing in sandy pine-barrens from North Carolina to Florida. It is evergreen, with leaves like the Willow Oak, but thicker, and downy on the under surface.

No. 288. Quercus imbricaria, Michx.-Shingle Oak.-Eastern United States. A middle-sized tree, reaching to 50 or 60 feet high, and with a diameter of $1 \frac{1}{2}$ to 2 feet. It grows principally, in open situations, from New Jersey to Illinois and southward. Its foliage is handsome, resembling that of the Laurel. The wood is coarse-grained, and not durable.

No. 289. Quercus aquatica, Catesb.-Water Oak.-Southern States. A middle-sized tree, of the Southern States, growing on the borders of swamps. The leaves are perennial, of variable form, but always broadest at the upper portion and tapering to a point at the base.

No. 290. Quercus laurifolia, Michx.-Water Oak.-Southern States.

No. 291. Quercus nigra, L.-Black Jack.-Eastern United States. A small, scrubby tree, growing usually in poor clay soil. It is found in New Jersey, Maryland, and southward, as also in some of the Western States. The wood furnishes a good fuel, but is too coarse-grained and perishable for any use in the arts.

No. 292. Quercus falcata, Michx.-Spanish Oak.-Eastern United States. A large tree, attaining 80 feet or more in height, and sometimes 4 feet in diameter. It has about the same range as the Black Jack, not being found in New England nor in the northern part of the Western States. The wood is not valuable except for fuel.

No. 293. Quercus Catesbaei, Michx.-Turkey Oak.-Sonthern States. A small tree, with foliage much like the preceding. It is found in Florida, Georgia, and North and Soath Carolina. The wood is good fuel, but of no value as timber.

No. 294. Quercus rubra, L.-Red Oak.-Eastern United States. This is one of the largest oaks of our country, and is diffused over all the eastern portion of the United States, but more especially to the northward. It is a beautiful tree, with reddish, coarse-grained wood, which is little used in the arts except for barrel-stares.

No. 295. Quercus coccinea, Wang._-Scarlet Oak.-Eastern United States. The Scarlet and Quercitron Oaks do not differ much in their characters, and, indeed, are considered but as varieties of one species. They form large and handsome trees, and the bark furnishes a jellow dye which is used in the arts. 
No. 296. Quercus tinctoria, Bart.-Quercitron Oak.-Eastern United States.

No. 297. Quercus palustris, Du Roi.-Pin Oak.-Eastern United States. A rather smaller tree than the preceding. The leaves are small, smooth, of a pleasant green color, very similar to those of the Scarlet Oak. The wood is stronger and more durable than that species. It is chiefly limited to the Northern States.

No. 298. Quercus Sonomensis, Benth.-California Oak.-California. This species of California is nearly related to the Quercus rubra of the Eastern States. It grows in mountainous districts, and forms a pretty large tree.

No. 299. Quercus Wislizenii, DC.-California Live Oak.-California. A smallish tree of California, with bright-green persistent leaves, sometimes called Live Oak.

No. 300. Quercus dumosa, Nutt.-Dwarf Oak.-California. This is a common dwarf oak in Southern California.

No. 301. Quercus reticulata, H.B. K.-Dwarf Oak.-Southern Arizona.

No. 302. Castanea vesca, L., var. Americana, Gr.-American Chestnut.Eastern United States. One of the noblest trees of American forests. It occurs from Massachusetts to Michigan, and in the mountainous dis. tricts of Pennsylvania, Virginia, and Tennessee, but not on the prairie regions of the Western States. The wood is strong, elastic, and durable, and is largely employed in the manufacture of furniture and for the inside finish of railroad-cars and steamboats. The nuts are very sweet and palatable, and always command a good price in the markets.

No.303. Castanea pumila, Michx._Chincapin.-Southern States. This may be called a dwarf chestuut, growing from New Jersey and Pennsylvania to Florida. Northward it is only a large shrub, but in South Carolina and Florida it becomes a tree of 30 to 40 feet high and 12 to 15 inches diameter. The wood equals that of the chestnut, but the nuts, although generally eaten by children, are not comparable to those of the former.

No. 304. Castanopsis chrysophylla.-California Chestnut.-California. A tree of Uregon and California, becoming 60 to 100 feet high and 2 to 3 feet diameter. The bur is scarcely one-third as large as in the common chestnut, with shorter prickles. The shell of the nut is almost as large as the filbert.

No. 305. Castanopsis chrysophylla, var. pumila.-California Chincapin. -California. This is mostly a shrub growing on open mountain-sides, and is sometimes called California Chincapin.

No. 306. Fagus ferruginea, Ait.-Beech.-Eastern United States. The Beech is one of our loftiest trees, sometimes reaching the height of 100 feet. It grows from Canada to the Gulf of Mexico. It is wanting in the prairie districts of the West. The wood is hard, fine-grained, and compact. It is largely used for shoe-lasts and bandles of tools. . It is also employed in the frame-work of buildings. The wood is in great repute as fuel. The nuts have a delicious flaror, but are too sinall to make them of much economic importance.

No. 307. Carpinus Americana, Michx.-Blue Beech.-Eastern United States. A small tree 15 to 20 feet high. The rood is white, compact, and fine-grained.

No. 308. Ostrya Virginica, Willd.-Hop Hornbeam ; Ironwood.-Eastern United States. The Irouwood is a small tree, but sometimes grows to a height of 40 feet. The wood is heary and fine-grained, and is used for mallets, wedges, levers, \&c. Its growth is very slow.

No. 309. Corylus rostrata, var. Californica.-California. 


\section{MyricACEA.}

No. 310. Myrica cerifera, L.-Bayberry ; Wax Myrtle.-Eastern Unit. ed States. A shrub or small tree growing near the sea-coast. The berries are coated with a waxy secretion, which is sometimes utilized in the domestic manufacture of candles and also in medicinal unguents.

No. 311. Myrica inodora, Bart.-Florida Bayberry.-Florida.

No. 312. Myrica Californica, Cham.-California Bayberry or Myrtle.California. This species sometimes attains a height of $40 \mathrm{feet}$, with a trunk 2 feet in diameter. It grows on the Pacific coast, from Puget Sound to Mexico.

\section{Betulace AE.}

No. 313. Betula alba, var. populifolia, Spach.-American White Birch. - Northern and Northeastern United States. A small and slender graceful tree, 15 to 25 feet high, growing from Maine to Pennsylvania, and sparsely on the great lakes.

No. 314. Betula papyracea, Ait.-Canoe Birch ; Paper Birch.-Northern and Northeastern United States. A large and handsome tree, growing to the height of 70 feet, and with a diameter of 3 feet. It is linited to the northern portions of the country, ranging from Maine to Wisconsin on the northern border, and extending far northward into Canada. It has a brilliant white bark, from which Indians and traders construct canoes. The thin, external sheet of the bark forms the basis of a great variety of Indian fancy-work.

No. 315. Betula lutea, Michx.-Yellow Birch.-Northern and Northeastern United States. This is a beautiful large tree, growing in moist woods on our northern border. The wood is strong, fine-grained, and makes handsome furniture.

No. 316. Betula lenta, L.-Cherry Birch; Black Birch.-Northern and Northeastern United States. This, like the preceding, is a large tree, chiefly of our northern borders, but extending also along the Alleghany region southward. The bark and twigs are highly aromatic. The wood is of a rosy hue, fine-grained, and valuable for cabinet-work and for timber.

No. 317. Betula nigra, L.-River Birch; Red Birch.-Eastern United States. This becomes a large tree in favorable situations. It is found along the banks of rivers from Eastern Massachusetts southward to Florida, and westward to Kentucky, Illinois, and Iowa. The wood is similar to that of the preceding.

No. 318. Betula occidentalis, Hook.-Western Birch.-Rocky Mountains. This species is a small tree, rarely over 25 feet high and 6 inches in diameter. It is found in the Rocky Mountains, along streams; in Colorado, Utah, \&c.

No. 319. Alnus incana, Willd.-Speckled Alder.-Northeastern United States. A shrub, or small tree, growing along streams in New England, New York, and northward. Of no particular value.

No. 320. Alnus rhombifolia, Nutt.-California Alder.-California.

No. 321. Alnus Oregona, Nutt.-Oregon Alder.-California and Oregon. On the Pacific coast, in California and Oregon. Often becoming a large tree, 60 to 80 feet high, with a trunk 2 feet in diameter.

\section{SALICACE E.}

No. 322. Salix nigra, Marshall._Black Willow.-Eastern United States. This is almost the only willow of the eastern portion of the 
continent which attains a tree size. It grows from 20 to 30 feet high, with a thick black bark. On the Pacific coast are several species which become tree willows.

No. 323. Salix nigra, var. Purshiana.-Willow.-Texas.

No. 324. Salix longifolia, Muhl., var.-California Long-leared Willow. -California.

No. 325. Salix Wrightiana, Aud.-Wright's Willow.-Texas.

No. 326. Salix lasiolepis, Benth.-Willow.-California.

No. 327. Salix lucida, Hook., var.-California.Shining Willow.-California.

No. 328. Populus tremuloides, Michx.-American Aspen.-Eastern United States and Rocky Mountains. A small tree of the northern border and Canada, also found on mountain-sides through the Rocky Mountains.

No. 329. Populus grandidentata, Michx.-Great-toothed Aspen.Eastern United States. This is a larger tree than the preceding, common in the Northern States, and extending southward along the Alleghany Mountains. It much resembles the European Silver Poplar.

No. 330. Populus monilifera, Ait.-Cottonwood.-Eastern United States and Rocky Mountains. This and the next species of cottonwoods have a wide range throughout most parts of the United States. Some botanists consider them to be but forms of one species. They are large, rapidly-growing trees, particularly abundant in the prairie regions and western river-banks, extending even to the Pacific Ocean. The wood is light and soft, much employed in some of the Western States for building purposes, and for inside. work of houses, under the name of Whitewood and Cottonwood.

No. 331. Populus angulata, Ait.-Cottonwood.--Sonthern States.

No. 332. Populus heterophylla, L.-Swamp Cottonwood.-Eastern United States. This species prevails in the Southern States, but extends northward as far as Delaware and Southern Illinois. It is a large tree, growing chiefly in swampy woods, and little valued.

No. 333. Populus balsamifera, L.-Balsam Poplar.-Northeru and Westèrn United States. This species grows mostly in northern latitudes, being found in New England and Northern New York, also in the Rocky Mountains. It is a large tree; a variety of it is in cultivation.

No. 334. Populus angustifolia, James.-Willow-leaved Cottonwood.Rocky Mountains. This is now considered to be a variety of the preceding: It is found principally along streams in the Rocky Mountains, where it is called Cottonwood, sometimes Willow-leaved Cotton rood.

No. 335. Populus trichocarpa, Torr.-Cotton wood.-California.

\section{CoNIFER E.}

No. 336. Pinus Banksiana, Lamb.-Banks's Pine; Scrub Pine.-IVisconsin to New England. This species is found from the northern parts of the United States nearly to the Arctic Ocean, and from Labra. dor to the Saskatchawan. In Wisconsin it becomes a middle-sized tree, and is used for timber when the trees are found of sufficient size.

No. 337. Pinus contorta, Dougl.-Twisted pine.-Rocky Mountains. This tree is found in the Rocky Mountains from Colorado to Oregou. It differs widely in regard to size in different localities. Near the Paci. fic coast it is often low and scrubby, bearing cones at 5 feet high. In Colorado it is found at an altitude of 7,000 feet, and attains a height of 5 () feet.

No. 338. Pinus contorta, Doug., rar. Bolanderi.-Bolander's Pine.- 
California. This variety in the Sierra Nerada Mountains at an altitude of 5,000 to 9,000 feet attains a height of 150 to 200 feet. It is variously called Tamarack, Twisted Pine, or Black Pine.

No. 339. Pinus inops, Ait.-Jersey Pine; Scrub Pine.-Eastern United States. A straggling tree 15 to 40 feet high, with spreading or drooping branches. It abounds in New Jersey, Maryland, and Virginia, also on the rocky hills bordering the Ohio in Kentucky, Southern Illinois, and Indiana. The wood is of little value.

No. 340. Pinus mitis, Michx.-Yellow Pine.-Eastern United States, chiefly south. This is a handsome tree, growing from New England to Wisconsin, and sparingly in Missouri, Kentucky, Tennessee, and south ward to Florida. The timber is very valuable, commanding a higher price even than the white pine.

No. 341. Pinus clausa, Chap.-Florida. A small tree found b5 Dr. Chapman at Apalachicola, related to Pinus inops.

No.342. Pinus glabra, Walt.-Spruce Pine.-Sonth Carolina and south ward. A tree 40 to 60 feet high, with smoothish bark and soft white wood, branching from near the ground. Resembles P. mitis; grows from South Carolina to Florida.

No. 343. Pinus resinosa, Ait.-Red Pine.-Massachusetts to Wisconsin. A tree 50 to 80 feet high, with reddish bark, growing from Pennsylvania northward through Canada and Nora Scotia, also in Wisconsin and-Michigan. The wood is compact, strong, and durable, and for some uses is preferable to the white pine. It is also an excellent ornamental tree.

No. 344. Pinus Elliottii, Eng._Elliott's Pine.-South Carolina and southward.

No. 345. Pinus pungens, Michx.-Table Mountain Pine.-This species grows on the Alleghany Mountains from Pennsylrania southward; abundant in some parts of Virginia and North Carolina. A tree of 40 or 50 feet height, and of very vigorous and rapid growth.

No. 346. Pinus muricata, Don.-Bishop's Pine.-California. A small tree 30 to 40 feet high; grows near the coast north and south of San Francisco, and in other localities in that State.

No. 347. Pinus edulis, Eng.-Piñon Nut Pine.-Rocky Mountains. A low tree with a spreading habit, growing in Colorado and Utah, and in New Mexico, Arizona, and Southern California. It is universally known by the Mexican name of Piñon. It has an edible nut, which is much used as food by the Indians, and the mood is rich in resin, making it excellent fuel.

No. 348. Pinus monophylla, Torr.-Nut Pine.-Sierra Nevada Mountains. This species is almost limited to the eastern slope of the Sierra Nevada Mountains, at altitudes of 2,000 to 6,000 feet. It is a small tree of 20 to 40 feet height. The seeds are eagerly collected for food by the Washoe and other Indians. The wood is excellent fuel.

No. 349. Pinus Parryana, Eng.-Nut Pine.-Near the Mexican border southwest.

No, 350. Pinus ponderosa, Dougl.-Yellow Pine.-Rocky Mountains. A very variable pine; several of its extreme forms have been considered different species. It occurs in Colorado, Utah, and the Black Hills of Wyoming. It is remarkable for its heary wood, which makes excellent lumber. It is generally called Yellow Pine.

No. 351. Pinus ponderosa, Doug., var. Benthamiana, Hart. - Sappy Pine.-California. This variety grows in the Sierra Nevada Mountains, in damp ralleys, and near streams. It is generally slender and tall, 
with low limbs, black bark, and sappy, tough wood. Used for building-timber, flooring, \&c. It has several names, as Swamp Pine, Sappy Pine, Black Pine, and Bull Pine.

No. 352. Pinus ponderosa, Doug., var. Jeffreyi, Balf.-Jeffrer's Pine.California. This variety also grows on the Sierra Nevada Mountains, and on the Coast Range of California. It often attains a height of 170 to 250 feet and a diameter of 6 to 10 feet. It differs much in the quality of the wood, but is used for all the purposes of other kinds. It is remarkable for the comparatively large size of its cones. It is called Yellow Pine, Pitch Pine, and Truckee Pine.

No. 353. Pinus australis, Michx.-Long-leared Pine.-South Carolina and southward. A lofty tree, growing in the pine-barrens of the Southern States, attaining a height of 75 to 100 feet. Next to the White Pine, this is perhaps the most valuable of the genus. The timber plays an important part in ship-building, is extensirely used as a flooring, and in house-building. The chief value of this species is for the turpentine, tar, pitch, and rosin which it supplies, and of which immense quantities are exported in addition to the home supply.

No. 354. Pinus Coulteri, Doug.-Coulter's Pine.-California. A large tree of California, from 80 to 100 feet in height, with large, spreading branches, and a trunk 3 or 4 feet in diameter. The cones are heavier than those of any other of the family, being frequently 1 foot long and 6 inches diameter, and weighing from 4 to 6 pounds. The large, nutlike seeds contained in the cones are nutritious, and used as an article of food by the Indians.

No. 35̃. Pinus Sabiniana, Doug.-Hard-nut Pine; Sabine's Pine.California. Grows on the foot-hills of the Coast Range and on the westeru foot-hills of the Sierra Nevada Mountains of California. It is not rery abundant, and is limited by the altitude of 4,000 feet. It grows from 40 to 100 feet high. The cones are large and heavy, and full of oily, nutritious nuts, which are used by the Indians. The timber is fit only for fuel. It is called Digger Pine, Foothill Pine, Gray-leared Pine, \&c.

No. 356. Pinus Torreyana, Parry.-Torrey's Pine.-California. A species of Southern California, resembling the preceding, but smaller. The nuts are thick-shelled, but nutritious, and used as food by the Indians.

No. 357. Pinus insignis, Dougl.-Monterey Pine.-Ualifornia. Grows along the coast south of San Francisco. Some old trees near Monterey are 70 or 80 feet high. It is quite an ornamental species, and is in frequent cultivation in California.

No. 358. Pinus radiata, Don.-Calitornia.

No. 359. Pinus tuberculata, Don.-Prickly-coned Pine.-California. A small tree seldom attaining a greater height than 30 to 40 feet, with a trunk of 8 or 10 inches diameter. It grows on the Coast Hills south of San Francisco, and in other places in the State.

No. 360. Pinus rigida, Miller.-Pitch Pine.-Eastern United States. A medium-sized tree from 30 to 70 feet high, with dark, rugged-looking bark, and hard, resinous wood. The wood is knotty, and of little value for lumber, but gires an intense heat in burning on account of the quantity of resin which it contains.

No. 361. Pinus serotina, Michx.-Pond Pine.-Southern States. This is closely related to the preceding, and is by some considered only at variety of it. It grows on the borders of ponds and swamps from Florida to North Carolina.

No. 362. Pinus'Tada, I_LLoblolly; Old-field Pine.-Southern States. A species confined to the Atlantic States, growing mostly in damp or in light, barren soil, frequently taking possess:on of old and neglected 
fields. It is variable in height, sometimes rising to 70 or 100 feet high. 'The timber is said to be raluable, though less so than that of $P$. australis.

No. 363. Pinus aristata, Eng.-Prickly-coned Pine.-Rocky Mount. ains. This species was first found in Colorado near Pike's Peak, but it is now considered to be synonymous with the next.

No. 364. Pinus Balfouriana, Jeffrey.-Balfour's Pine.-Rockr Monntains. The specimen is from Southern Utah, and grows on high, barren, sandstone mountains : it grows about 50 to 60 feet high. The tree is distinguished by its long branches, which are heavy, causing the ends to hang down. The tree is compact in appearance and of very dark-green color. It is thought by some that the tree of Oregon, which has been described under this name, is a different species.

No. 365. Pinus flexilis, James.-Bull Pine.-Rocky Mountains. This is the prevailing pine of the East Humboldt Mountains, Nerada, and frequent in the Wasatch. It also grows in Colorado and on the San Francisco Mountains of Arizona. In the Wasatch Mountains it is found at high altitudes on limestone ledges, and has a branched and knotty habit, rendering it unfit for lumber. It is called by the inhabitants Bull Pine. It is a middle-sized tree, usually 30 to 50 feet high, but recorded by Fendler as 60 to 80 feet high near Santa Fé.

No. 366. Pinus albicaulis, Eng.-White-barked Pine.-Rocky Mountains. This species, although closely related to the preceding, is believed to be different. It grows only at extreme altitudes. It grows on the Cascade Mountains of Oregon, on alpine peaks in the Sierra Nevada Mountains, and on high mountains in Idaho and Montana. The name is suggested by the color of the bark of the tree, which Dr. Engelman says is as white as milk.

No. 367. Pinus Lambertiana, Doug.-Sugar Pine.-Sierra Nevada Mountains. Found sparsely growing on the Sierras of California, through their extent, at altitudes of from 4,000 to 10,000 feet. It is often 150 to 220 feet high, with a diameter of 8 to 14 feet. It is highly prized and eagerly sought by lumbermen for all articles of buildinglumber, and is fast being exhausted. It is called Sugar Pine from the sweet resin which exudes from partially-burned trees. It is also called Mammoth Pine and Shake Pine. It has enormous cones.

No. 368. Pinus monticola, Dougl.-_Soft Pine; Little Sugar Pine.California. Grows sparsely on the high Sierras, at altitudes of 7,000 to 11,000 feet. It sometimes attains a height of 150 to 200 feet, with a diameter of 5 to 7 feet. It resembles the Sugar Pine, but with whitish, much furrowed, bark and smaller cones. The timber is similar to that of White Pine, but is seldom used, because the trees are so inaccessible.

No. 369. Pinus strobus, L.-White Pine; Weymouth Pine.-Eastern United States. An old, well-known, and useful tree, extending from Canada to Virginia, but plentiful in New England, New York, and Pennsylvania. It is a large tree, becoming 100 to 150 feet high. It is the source of much of the lumber brought from the Northern States. It is not only very valuable on account of its rood, but is one of the finest ornamental conifers.

No. 370. Pinus Chihuahua, Eng.-Southern Arizona and Northern Mexico.

No. 371. Abies alba, Michx.-White Spruce.-New England and Alleghany Mountains. A small tree, native of the northern portion of the United States and Canada, extending northward to the extreme confines of vegetation. It grows from 20 to 30 feet high, according to soil and latitude. It is frequent in cultivation, and is considered a handsome tree. 
No. 372. Abies nigra, Poir.-Black Spruce.-New England and Alle. ghany Mountains. This tree has much the same range as the preceding, occasionally being found farther south on the Alleghanies. In favorable situations, it forms quite a large tree, about 75 feet high, tall and straight. The wood is light, elastic, and strong, and valuable for mans purposes.

No. 373. Abies Canadensis, Michx.-Hemlock.-New England to Wisconsin. A well-known tree of the Northern States, extending northward to Hudson's Bay, and southward along the mountains to North Carolina. It is one of the most graceful of spruce's, with a light and spreading spray, frequently branching almost to the ground. The wood is coarse-grained, but is used in great quantities for rough work. The bark is very extensively emplosed in tauning.

No. 374. Abies Mertensiana, Lind.-Western Hemlock.-Oalifornia and Oregon. This tree closely resembles the A. Canadensis. It grows from 100 to 150 teet high, and forms a roundish, conical head. The timber is said to be soft and white, and difficult to split.

No. 375. Abies Williamsoni, New.-Williamson's Spruce.-Califoruia and Oregon. Grows on the Sierras of California and on the Cascade Mountains of Oregon, on high peaks of 8,000 to 12,000 feet altitude. A very graceful tree, attaining a height of 150 feet. The wood is of excel. lent quality, but is too rare and inaccessible to be much known.

No. 376. Abies Douglasii, Lind.-Douglas's Spruce.-Rocky Mountains. This species grows through the Rocky Mountain region from Colorado to Nootka Sound. On the Pacific coast, it sometimes attains the immense size of 200 to 300 feet in height, and a diameter of trunk of 8 to 15 feet. Its timber composes the great lumber wealth of Oregon and Washington Territory. The wood is soft and easily worked, much prized for masts, spars, and plank for ship-building, and is equally valuable for other building purposes. A tree cut by Mr. A. J. D)ufur was 6 feet 4 inches in diameter 30 feet from the base, and 321 feet long.

No. 377. Abies Douglasii, var. macrocarpa, Torr. - Large-coned Spruce.-Southern California. This was collected many sears ago on the mountains east of San Diego, Cal.; in $\mathbf{1 8 7 4}$ sent to the Department of Agriculture by Mr. F. M. Ring, of San Bernardino, Cal.: and collected last summer by Dr. Palmer at San Felipe Cañon, east of San Diego. It has cones four or five times the size of Douglasii, and will probably be confirmed as a new species.

No. 378. Abies Menziesii, Dougl.-Menzies's Spruce.-Rocky Mountains. This species has a wide range in the Rocky Mountains from Colorado and Utah to Oregon and Sitka. It grows mostly at high altitudes, 7,000 to 9,000 feet. "In Utah," Mr. Ward says, " it is easily distinguished from the other firs by the dense masses of its long, pendant, dark-brown cones at the top of the tree, which frequently obscure the foliage. The wood is fine-grained and white, and would be valuable for timber but for the numerous slight curves in the trunk, which render it impossible to obtain saw-logs of any great length. In some places it is incorrectly called balsam; in others it is distinguished as spruce." Mr. Dufur, of Oregon, gives a somewhat different account of the tree as growing there. He says: "It grows along the tide-lands and about the mouth of the Columbia River, and is seldom found at an elevation of more than 500 feet. The young trees make a beautiful evergreen of pyramidal form. The large trees grow from 150 to 200 feet high, and from 2 to 6 feet in diameter. The wood is soft, white, and free, much prized for lumber."

No. 379. Abies Engelmanni, Parry.-Engelmann's Spruce.-Rocky 
Mountains. This species is found on the higher parts of the Rocky Mountains, from New Mexico to the headwaters of the Columbia and Missouri Rivers. In Colorado, it occupies a belt between 8,000 and 12,000 feet, reaching its fullest development between 9,000 and 10,000 feet. On the highest summits, it becomes a prostrate shrub. Mr. Ward, writing of the tree in Utah, says: "Between 9,000 and 10,000 feet altitude, it becomes a large and noble tree, and is of the greatest value for lumber, taking the place in that region of the White Pine of the Eastern States, and is alone known by that name among lumbermen. The wood is white, very light, and easily worked, and at the same time durable." Botanically, it is difficult to distinguish it from some forms of A. Menziesii.

No. 380. Abies balsamea, Marshall.-Balsam.-New England to Wisconsin. This species grows in cold, damp woods and swamps, from New England to Pennsylrania, Wiscousin, and northward. It is also a native of Canada and Nova Scotia. It generally grows about 20 to 40 feet high. It is a very popular ornamental tree. "A very aromatic liquid resin is obtained from this tree by incisions made in the bark, and is called Canada Balsam."

No. 381. Abies sub-alpina, Eng.-Sub-alpine Balsam.-Rocky Mountains. This is one of the tallest and handsomest firs of the Rocky Mountains, often attaining a beight of 80 or 90 feet; perfectly straight, and without limbs for a great distance. The wood is white, soft, and of little ralue for lumber. It is known among the lumbermen of the Wasatch Mountains as White Balsam, or Pumpkin-tree. Its nearest affinity is to $A$. balsamea of the Easteru States. It reaches to great alti. tudes, being sometimes found near the timber-line. It has often been collected, and generally referred to $A$.grandis, the incorrectness of which has been but lately pointed out by Dr. Engelmann, who has proposed for it the name given abuve.-(Ward.)

No. 382. Abies grandis, Lind.-White Silver Fir.-California and Oregon. This name is here applied to the tree of the Pacific coast. "In Oregon," Mr. Dufur says, "it grows on the low, moist land, along the small streams emptying into the Columbia River. Is seldom found at an elevation of more than 500 feet, and nerer on sandy or gravelly ridges. It attains a size of from 2 to 4 feet in diameter, and 200 feet in height. It has a light-colored, thin, smooth bark. It is a rapid grower, and the timber decays correspondingly fast when exposed to the wet. The wood is white, free, and soft, but too light and brittle for general building purposes. It is used extensively by the settlers for clapboards, boxes, and cooperage."

No. 383. Abies concolor, Eng.-White Silver Fir.-Rocky Mountains. In the Wasatch Mountains in Utah this tree is very valuable for lumber, and is called Black Balsam. It is there a large tree, sometimes 3 or 4 feet in diameter and 40 to 50 feet high. The wood is tough and coarsegrained, adapting it for building purposes and all substantial uses. It ranges from 8,000 to 9,000 feet in altitude.-(Ward.) In Southern Utah, it is sometimes called Black Gum.

No. 384. Abies amabilis, Dougl.-Red Silver Fir.-California and Oregon. Mr. Lemmon states, "Un the Sierra Nevada Mountains, it forms dense, scattered groves, at altitudes of 7,000 to 10,000 feet. The largest trees are 250 feet high and 6 to 10 feet in diameter. A truly beautiful and magnificent tree, sometimes called the Queen of the Forest." Mr. Dufur says it is found extensively along the western slope of the Cascade Mountains, on sandy, gravelly, rocky, and dry elevations. Its usual size is from 150 to 200 feet in height, and from 1 to 4 feet in diameter. The wood is rather coarse, but elastic, strong, and hard. It 
is used extensively for coarse building purposes, and also for masts and spars for ship-building. The wood has a peculiar red color, and spikes, nails, and bolts hold firm, and never corrode in the timber.

No. 385. Abies Fraseri, Pursh.-Fraser's Balsam.-Alleghany Mountains. This species inhabits the highest parts of the Alleghanies, in North Carolina. It is said to be a small tree, ranging from 20 to 50 feet in height. The cones resemble those of $A$. nobilis in miniature.

No. 386. Abies nobilis, Lind.-The Noble Fir.-Oregon. This is one of the magnificent conifers of our country. It is a majestic tree, forming rast forests on the mountains of Northern California and Oregon. The Indians give it the name of Big Tree. The timber is said to be of ex. cellent quality. It is nearly related to $A$. Fraseri, but has cones fire times as large.

No. 387. Abies bracteata, Hook.-Bracted-coned Spruce.-Oregon. This species grows on the higher mountains of Oregon. It was also found by Dr. Coulter in Sonthern California. It is little known. The cones are very curious and remarkable, being handsomely fringed by long leaf-like bracts, entirely different from those of any other species.

No. 388. Larix Americana, Michx.-American Larch.-New England to Wisconsin. This species is seldom found so far south as Virginia; its favorite localities being the New England States, Northern New York, westward to Wisconsin, and northward to Canada. In Canada, it is called Hackmatack; in some portions of New England and New Jersey, Tamarack. The quality of the wood is represented as being snperior to any kind of pine or spruce.

No. 389. Larix Lyallii, Parl.-Lyall's Larch._Oregon.

No. 390. Larix occidentalis, Nutt.-Western Larch.-Oregou. Mr. Dufur says this species is found abundantly in the Blue Mountains in Eastern Oregon, also well up in the Cascade and Coast Ranges, but seldom at an elevation of less than 3,000 feet. It is often found 250 feet high, and attains a diameter of 5 feet, frequently being found 200 feet to the first limb. The timber is rery strong and durable, free to split, and used for all kinds of fencing and coarse building.

No. 391. Torreya taxifolia, Arn.-Yew-leaved Torreja.-Florida. A small tree from 20 to 40 feet high, found on the east bank of the Apalachicola River in Florida. It is called by the inhabitants Stinking Yew, from the unpleasant odor of the bruised leares. The genus was named in honor of Dr. John Torrey, the late eminent botanist of New York. It is considered to be a very ornamental evergreen in cultivation.

No. 392. Torreya Californica, Torr.-California Nutmeg-tree.-California. This species grows near the coast in California. It sometimes attains the height of 60 feet, with a trunk 4 feet in diameter, but is usually a round-headed, small, compact tree, 20 to 40 feet high. The timber is said to be heavy and fine-grained. It is, like the preceding, called the Stinking Yew, from the unpleasant odor of the bruised leaves. The seeds have a rugose and mottled appearance, resembling a nutmeg, whence the name.

No. 393. Taxus brevifolia, Nutt.-Short-leaved Yew.-California and Oregon. A tree of California and Orgon, varying much in height in different localities. Dr. Newberry saw it forming an upright tree 50 to 75 feet in height and 2 to 3 feet in diameter. Mr. Dufur says it is found on the lowlands of Willamette Valley, is of slow growth, and seldom attains a height of 12 to 20 feet and a diameter of a foot. It is very scarce in all parts of Oregon. The small, red berries remain on the tree till late in the fall, and are used for food by the Indians. The wood is 
very hard aud durable, is capable of receiving a fiue polish, and is much prized for its fine grain, durability, and beauty.

No. 394. Taxus Floridana, Nutt.-Florida Ýw.-Florida. This species, so far as is known, is confined to a very limited field on the Apalachicola River in Florida. It is a small tree, from 10 to 20 feet high.

No. 395. Thuja occidentalis, L.-American Arbor Vitæ.-New England to Wisconsin. This tree is well known in cultivation, but in a native state is rarely found south of New York. In Canada and along the lakes, it is known as the White Cedar, which is the name given in New Jersey to the Cupressus thyoides. The Arbor Vitæ grows 25 to 50 feet high, forming a handsome, conical tree. The wood is light and soft, but durable, and is considerably used for building purposes. It is frequently emplojed as a hedge-plant and as an ornamental tree.

No. 396. Thuja gigantea, Nutt.-Giant Arbor Vitæ.-Oregon and Northwest coast. This tree is found in the greatest perfection on the western slope of the Cascade and Coast Ranges in Oregon and Wash. ington Territory, at an altitude of from 500 to 1,000 feet. It attains not unfrequently the enormous size of from 10 to 15 feet diameter and 200 feet in height. The timber is very soft, sinooth, and durable. It makes the finest sash, doors, moldings, \&c., and all kinds of building-lumber. The joung trees are beautiful ornamental evergreens, and make a handsome hedge.

No. 397. Thuja plicata, Don.-Nee's Arbor Vitæ.-Pacific coast.

No. 398. Cupressus thyoides, L.-White Cedar.-Middle and Southern States. This tree is found in swamps chiefly in the Atlantic States from Massachusetts to Florida. It has also been found near the Great Lakes. The tree rarely exceeds 70 or 80 feet in height, with a straight, tapering trunk. The wood is light, fine-grained, exceedingly durable, and easily worked. In New Jersey, it is largely made into shingles.

No. 399. Cupressus macrocarpa, Hart.-Monterey Cypress.-California. This is found in the vicinity of Monterey, Cal., where it grows 50 to 60 feet high, with a diameter sometimes of 3 to 4 feet. It is one of the finest cypresses known.

No. 400. Cupressus Nutkanus, Hook.-Nootka Cypress.-Oregon and the Northwest coast. This grows at Vancouver's Island and near Nootka Sound. It is a tall tree of 80 to 100 feet high. The timber is white, soft, and valuable.

No. 401. Cupressus Lawsoniana, Murray.-Lawson's Cypress._Mountains of Northern California.

No. 402. Cupressus MacNabiana, Murray.-McNab's Cypress.-Mountains of California and Oregon.

No. 403. Taxodium distichum, Rich.-Bald Cypress.-Southern States. This tree is found in all the Southern States, extending into Delaware and into Southern Illinois. In rich, alluvial bottoms, it frequently grows to the height of 120 feet. The roots often form large conical excrescences, called "cypress knees," which rise above the surface of the soil to the height of 2 to 4 feet. The wood is fine-grained, soft, elastic, strong, and exceedingly durable. Large quantities are made into shingles, and marketed at the North. Its foliage is delicate and beautiful, but is dropped during the winter.

No. 404. Sequoia sempervirens, End.-Redwood.-California. This is the mammoth tree of the coast of California, second only to the next species. It rises to the height of 200 to 300 feet, and sometimes with a circumference of 60 feet. The wood is dark red, rather light and brittle, but exceedingly durable, and makes valuable lumber.

No. 405. Sequoia gigantea, Torr-Giant Redwood.-California. This is the mammoth or big tree of California, growing in several groves on the 
western slopes of the Sierra Nevada Mountains, at an altitude of 5,000 to 9,000 feet. The largest trees are orer 300 feet high, and over 30 feet in diameter.

No. 406. Libocedrus decurrens, Torr.-Bastard Cedar.-California. This is sometimes called Red Cedar, or Post Cedar. It grows in the Sierras of California, at elevations of from 3,000 to 7,000 feet. It is a handsome tree, of low, conical form, tapering fast; 4 to 6 feet diameter at base; but only about 100 feet high. The wood is light and strong, and makes excellent cabinet-work, boxes, \&c.

No. 407. Juniperus Virginiana, L.-Red Cedar--Eastern United States. This is the Red Cedar of the eastern portion of the United States. It grows to the height of 30 or 40 feet, generally with a compact conical form. The timber is exceedingly valuable, being light, finegrained, compact, and durable. The heart-wood is of a handsome darkred color. It is used for a grent variety of ornamental work, and for fence-posts is almost imperishable.

No.408. Juniperus Virginiana, var. Bermudiana.-Pencil Cedar; Florida Cedar.-Coast of Florida. This variety, or species, as it is regarded by some, grows on the western coast of Florida. The wood is softer and freer from knots than the common form, and the pencil-manufacturers obtain their cedar wood from this source.

No. 409. Juniperus Virginiana, var. montana.-Rocky Mountain Red Cedar.-Rocky Mountains. A form or variety of Red Cedar found in Colorado and Utah. "In the Wasatch Mountains, Eastern Utah, this tree grows along the cañons containing water throughout the year, and not in dry places. Its form is there quite different from the Red Cedar in the East, being taller and with a looser and less symmetrical top. The people there say that the wood is not durable, and do not use it for fenceposts, \&c., as is doue with the eastern variety."

No. 410. Juniperus occidentalis, Hook.-Western Cedar.-Rocky. Mountains, California, and Oregon. This is undoubtedly the cedar named by Dr. Hooker $J$. occidentalis. It grows on the east side of the Cascade Mountains in Oregon and also in California. It is of slow growth, seldom attaining more than a foot in diameter and 30 feet in height. The wood is nearly all white, and harder than the Red Cedar.

No. 411. Juniperus occidentalis, var. Texana.-Rock Cedar.-Texas and westward. This forms extensive woods on rocky soil in Western Texas. The trunk is sometimes over one foot in diameter, jearly rings eccentric. It branches low, and forms almost impenetrable thickets. It is common fuel and fencing timber in Western Texas.-(Lindheimer.)

No.412. Juniperus Californicus, Carr. - Sweet-fruited Juniper.-Southern California. A cedar growing from San Felipe Cañon, in the Cusamaca Mountains, Southern California, into Arizona and Mexico. It is a dwarf tree, and is very prolific of berries, which are as large as large peas, of a somewhat resinous but sweet taste. The Indians consume large quantities of them for food. The seeds are large, smooth, and free, one or two in each berry.

No. 413. Juniperus Californicus, var. Utahense.-Western Red Cedar.Utah and California. This is the prevailing Cedar of the Wasatch Mountains, and ranging into Nerada and Southern California. In Eastern and Central Utah, this tree covers the slopes and foot-hills at from 5,000 to 7,000 feet altitude. It is low and spreading at the base, with a dense pyramidal top, light-green foliage, and large rather woody berries, not so nutritious as those of the preceding kind. The wood is extremely durable, and used for fence-posts. In Southern Utah, the berries are eaten by the Indians. The bark was formerly used by them in manufacturing many articles of clothing. 


\section{Palmace E.}

No. 414. Sabal Palmetto, R.\& S.-Cabbage Palmetto.-Coast of North Carolina and southward. The well-known Palmetto-tree of the Southern States, from North Carolina to Florida. It grows in sandy soil along the coast, with a stem from 20 to 40 feet high. The leaves are 5 to 8 feet long. "In the Southern States, the wood of this tree, though extremely porous, is preferred to any other for wharves," and when constantly under water is almost imperishable, but, when exposed to be alternately wet and dry in the flowing and ebbing of the tide, it decays as rapidly as other wood.

No. 415. Brahea edulis, Wad.-Guadalupe Palm.-Guadalupe Island. Guadalupe Island is off the coast of Lower California, 200 miles from San Diego. It is about twenty-six miles long by ten wide. It is owned by a chartered American company for the raising of Angora goats. On the island there is a palm.forest, of this species, of several thousand acres in extent. They grow from 12 to 20 feet high, and have a diameter of trunk of 8 to 15 inches. The fruit is about the size of a plum, hanging in clusters, like grapes, 2 feet long, weighing from 30 to 40 pounds, growing from one to four bunches to a tree. The fruit is eagerly eaten by goats.

No. 416. Pritchardia filamentosa, Wend.-California Palm.-Southern California. This palm has been in cultivation to some extent for several years, both in Europe and in this country, under the name of Brahea filamentosa. It has recently been decided to belong to a different genus: (Pritchardia.) It grows on rocky cañons near San Felipe, some seventy: tive miles northeast of San Diego, California. It grows to the height of 50 feet. The fruit is small, (as large as peas,) black, and pulpy. Though containing little nourishment, they are used as food by the Indians.

No. 417. Thrinax parviflora, Sw.-Silver Palmetto.-South Florida. This palm was found last fall by Dr. Chapman in South Florida. The stem is rarely 6 inches in diameter, yet they attain a height of 30 to 40 feet. "It occurs first at Cape Romans and is found sparingly on the mainland southward. It is more common on the keys, but I never heard of it before."-(Chapman.) The wood is quite dense; the berries white.

\section{LILIACE E.}

No. 418. Yucca Urevifolia, Eng.-Desert Yucca.-Arizona and Southern Utah. This singular tree grows in the deserts of Arizona and Southern Utah. It is from 10 to 20 feet high, with a trunk sometimes 10 or 12 inches in diameter. It is fibrous in all parts, so that the whole plant may be converted to paper.

No. 419. Yucca Treculiana, Carr.-Spanish Bayonet.-Western Texas and westward. Sometimes with a stem over 1 foot diameter and 50 feet high, branching only near the summit, every branch bears a thyrsus of flowers 3 to 4 feet high, each consisting of several hundred white fleshy flowers, shining like porcelain. The fruit is edible, resembling the papaw. The leaves are 2 to 4 feet long, deeply channeled, and pointer by a sharp thorn.-(Dr. Lindheimer.) 



